\title{
Preparation of Active Proteins, Vaccines and Pharmaceuticals as Fine Powders using Supercritical or Near-Critical Fluids
}

\author{
Stephen P. Cape, ${ }^{1,5}$ Joseph A. Villa, ${ }^{1}$ Edward T. S. Huang, ${ }^{1}$ Tzung-Horng Yang, ${ }^{4}$ John F. Carpenter, ${ }^{2}$ \\ and Robert E. Sievers ${ }^{1,3}$
}

Received January 10, 2008; accepted March 20, 2008; published online June 26, 2008

\begin{abstract}
Supercritical or near-critical fluid processes for generating microparticles have enjoyed considerable attention in the past decade or so, with good success for substances soluble in supercritical fluids or organic solvents. In this review, we survey their application to the production of protein particles. A recently developed process known as $\mathrm{CO}_{2}$-assisted nebulization with a Bubble Dryer ${ }^{\circledR}$ (CAN-BD) has been demonstrated to have broad applicability to small-molecule as well as macromolecule substances (including therapeutic proteins). The principles of CAN-BD are discussed as well as the stabilization, micronization and drying of a wide variety of materials. More detailed case studies are presented for three proteins, two of which are of therapeutic interest: anti-CD4 antibody (rheumatoid arthritis), $\alpha_{1}$-antitrypsin (cystic fibrosis and emphysema), and trypsinogen (a model enzyme). Dry powders were formed in which stability and activity are maintained and which are fine enough to be inhaled and reach the deep lung. Enhancement of apparent activity after CAN-BD processing was also observed in some formulation and processing conditions.
\end{abstract}

KEY WORDS: $\alpha_{1}$-antitrypsin; anti-CD4 antibody; CAN-BD; $\mathrm{CO}_{2}$-assisted nebulization with a bubble dryer; trypsinogen.

\section{INTRODUCTION}

Preparing protein therapeutics as dry powders is usually required in order to overcome stability problems that commonly plague liquid formulations. The most common process for making dry solid formulations of therapeutic proteins is freezedrying, also known as lyophilization (1). Another fairly common process is spray-drying, especially when the goal is to produce dry powders of therapeutic proteins and peptides (such as insulin) for pulmonary delivery (2). In the past decade or so, several supercritical fluid (SCF) or dense gas processes have received considerable attention as methods for producing particles containing a therapeutic agent or agents of interest that are suitable for pulmonary delivery or controlled release applications. ("Dense gas" is here defined as a gas in a supercritical, near-critical or liquid state.) In order for a powder to be suitable for pulmonary delivery, the aerodynamic size

\footnotetext{
${ }^{1}$ Center for Pharmaceutical Biotechnology, Department of Chemistry and Biochemistry and CIRES, University of Colorado, 215 UCB, Boulder, Colorado 80309, USA.

${ }^{2}$ Center for Pharmaceutical Biotechnology, Department of Pharmaceutical Sciences, University of Colorado Health Sciences Center, 4200 E. Ninth Avenue, P.O. Box C238 Denver, Colorado 80262, USA.

${ }^{3}$ Aktiv-Dry LLC, 6060 Spine Road, Boulder, Colorado 80301, USA.

${ }^{4}$ Biogen Idec, Inc., 5200 Research Place, San Diego, California 92122, USA.

${ }^{5}$ To whom correspondence should be addressed. (e-mail: Stephen. Cape@colorado.edu)
}

requirements are that particles must be in the 1 to $5 \mu \mathrm{m}$ range (3), but preferably in the 1 to $3 \mu \mathrm{m}$ range, with optimal size being $\leq 2 \mu \mathrm{m}$ (4). Production of particles in this size range is generally possible by applying one of the various SCF processes, provided that the pharmaceutical is soluble in a compatible solvent. An elegant and extensive review (albeit with a disclaimer by the authors that it is not exhaustive) has earlier been published that surveys the literature and patents covering the field of particle preparation using SCF (5). Jovanovic et al. (6) have summarized the narrower literature regarding the stabilization of proteins and drying by SCF technologies. In their review they discuss effervescent atomization, which includes in their terminology CAN-BD and supercritical assisted atomization (SAA). Shoyele and Cawthorne (7) have recently reviewed inhaled biopharmaceuticals manufactured by SCF technologies.

In the present review, we survey the application of various supercritical or near-critical fluid techniques to the preparation of protein powders and particles, and the progress to date and the limitations. For proteins and vaccines, the $\mathrm{CO}_{2}$-assisted nebulization with a Bubble Dryer ${ }^{\circledR}$ (CAN-BD) process $(8-12)$ appears to be a very promising new technology for the preparation of dry fine powders. This is due to the fact that CAN-BD can nebulize an aqueous solution without the need to use an organic solvent. Successful application of CAN-BD to both smallmolecule and protein macromolecule particle preparations is reviewed. Case studies on the CAN-BD processing of three proteins, two of which are of clinical therapeutic interest, are 


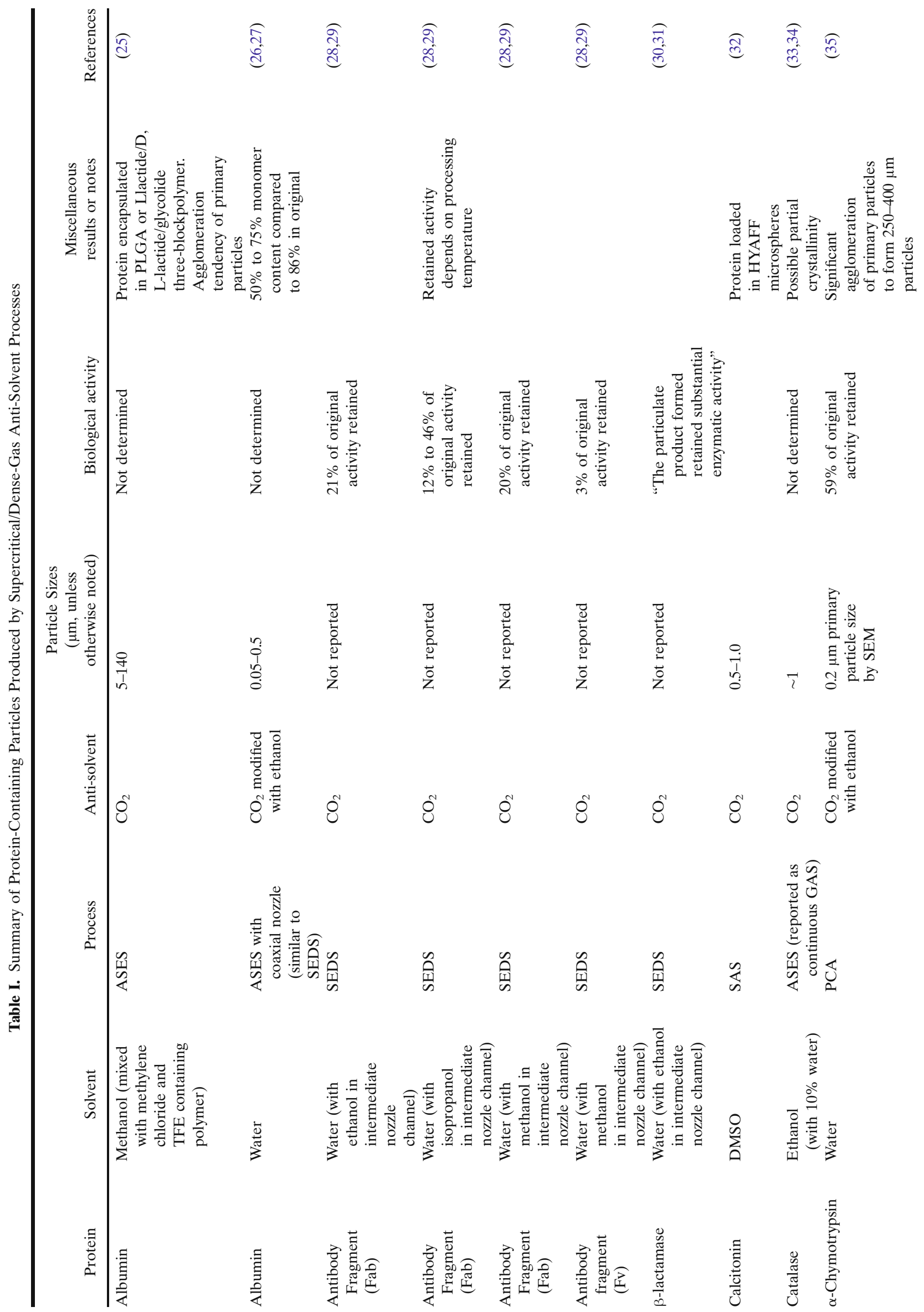




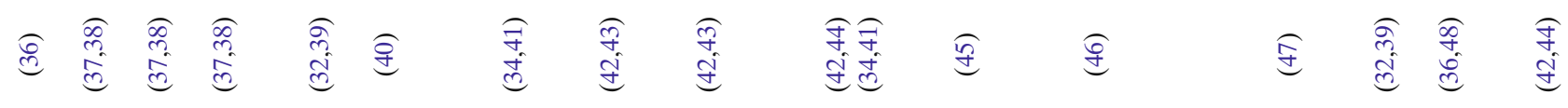
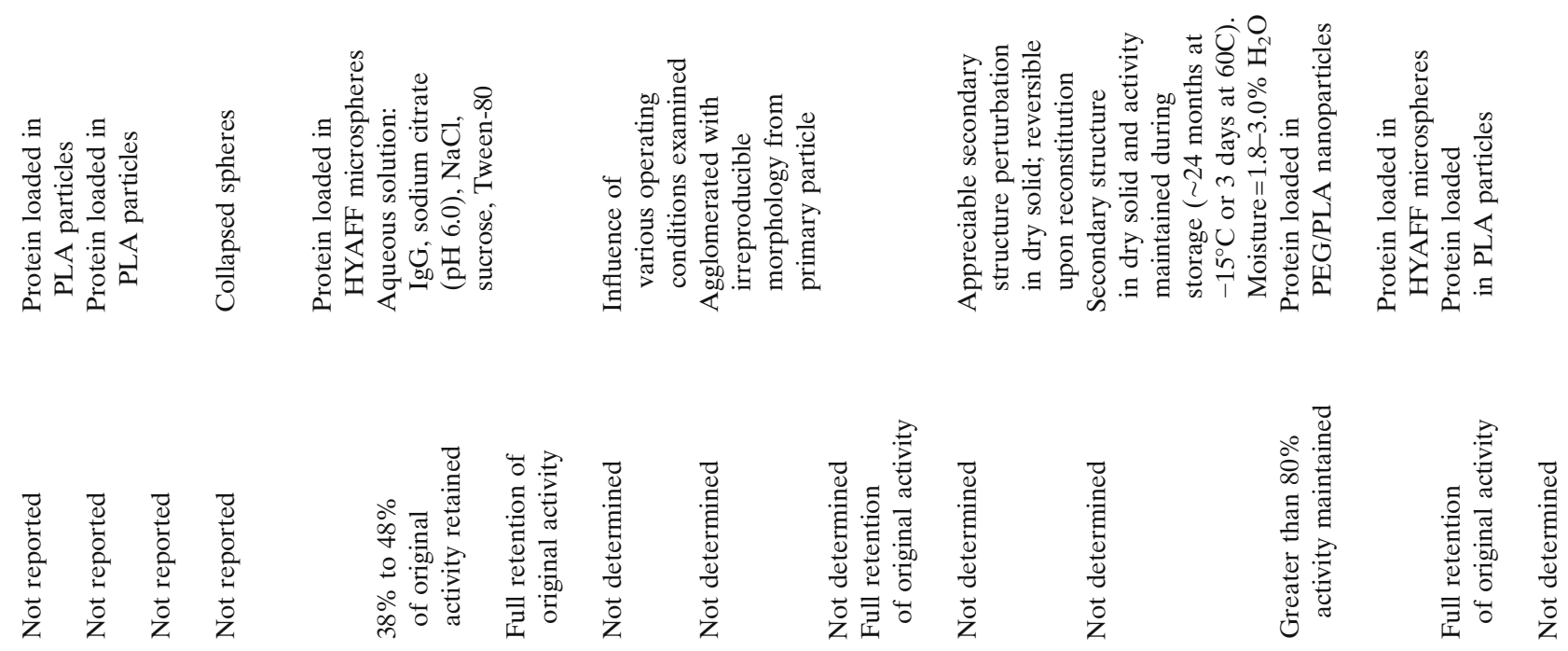

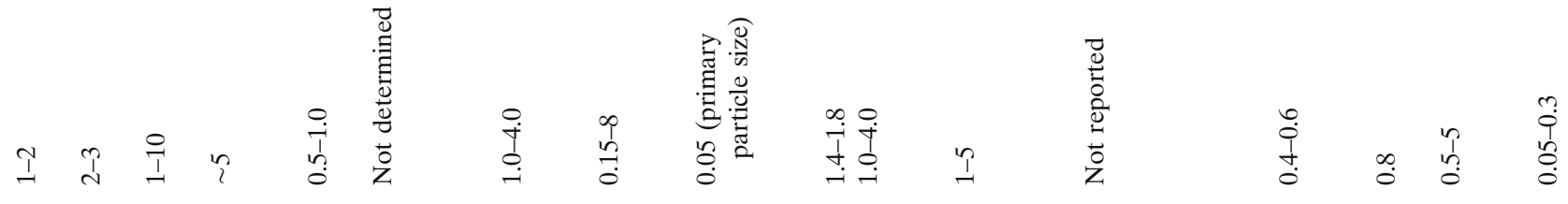

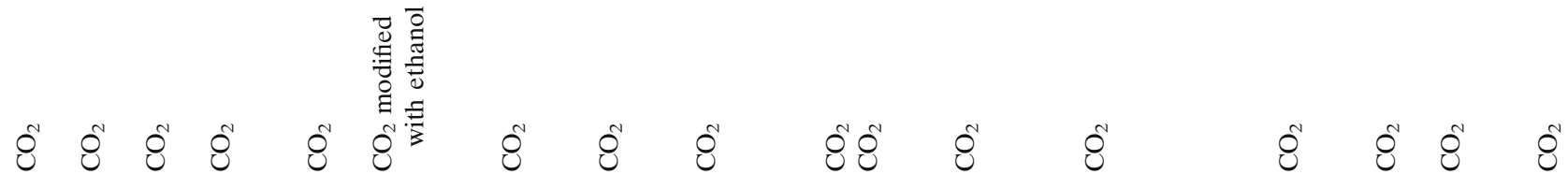

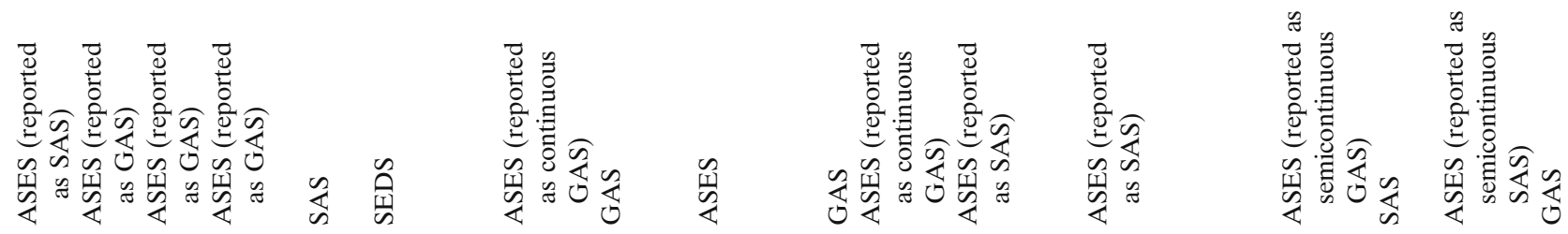

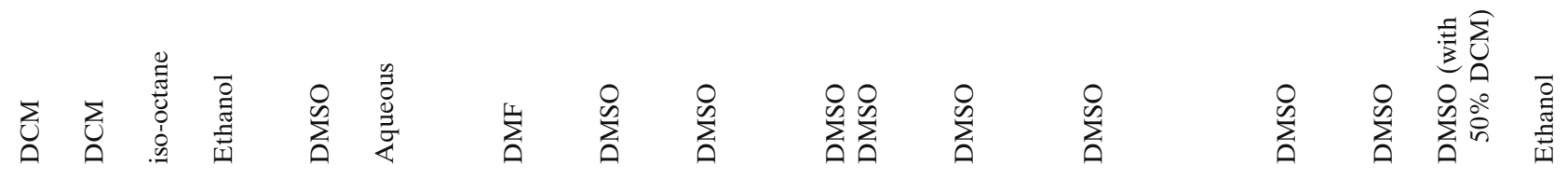

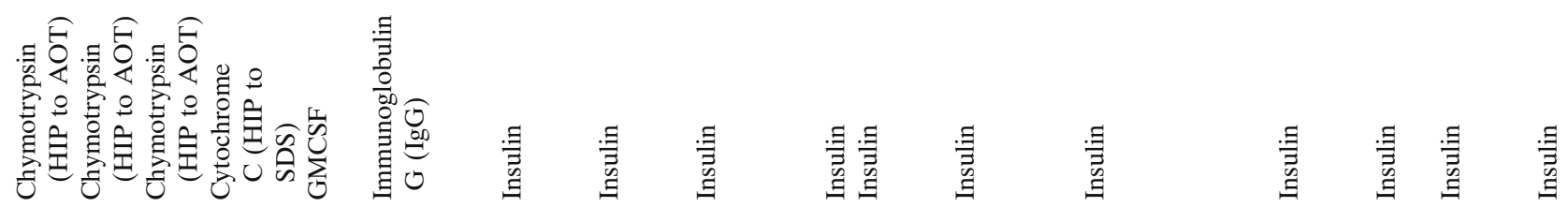




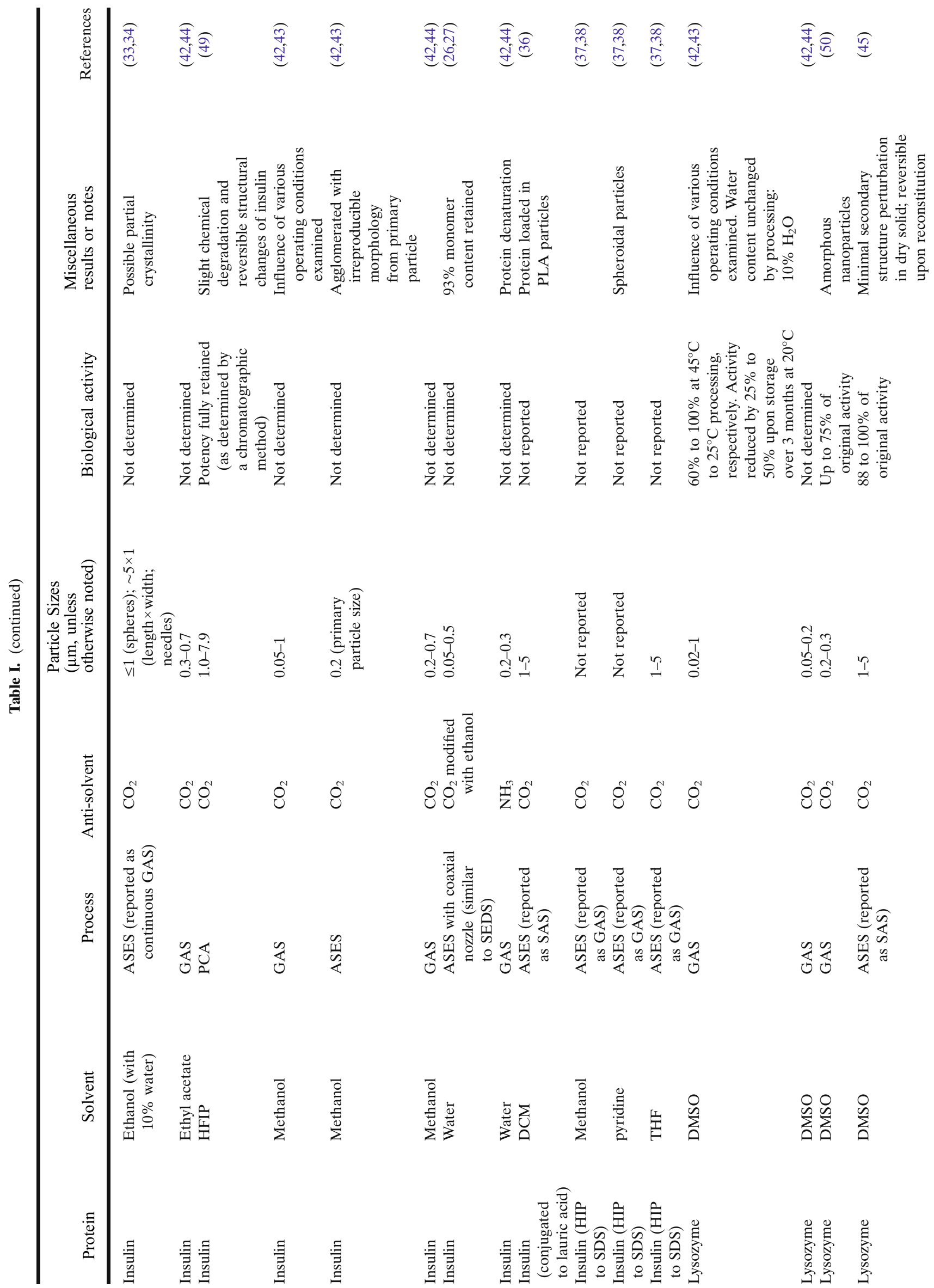




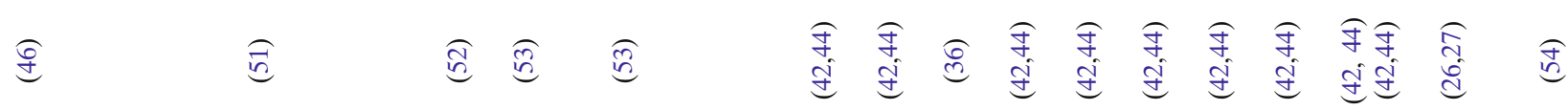
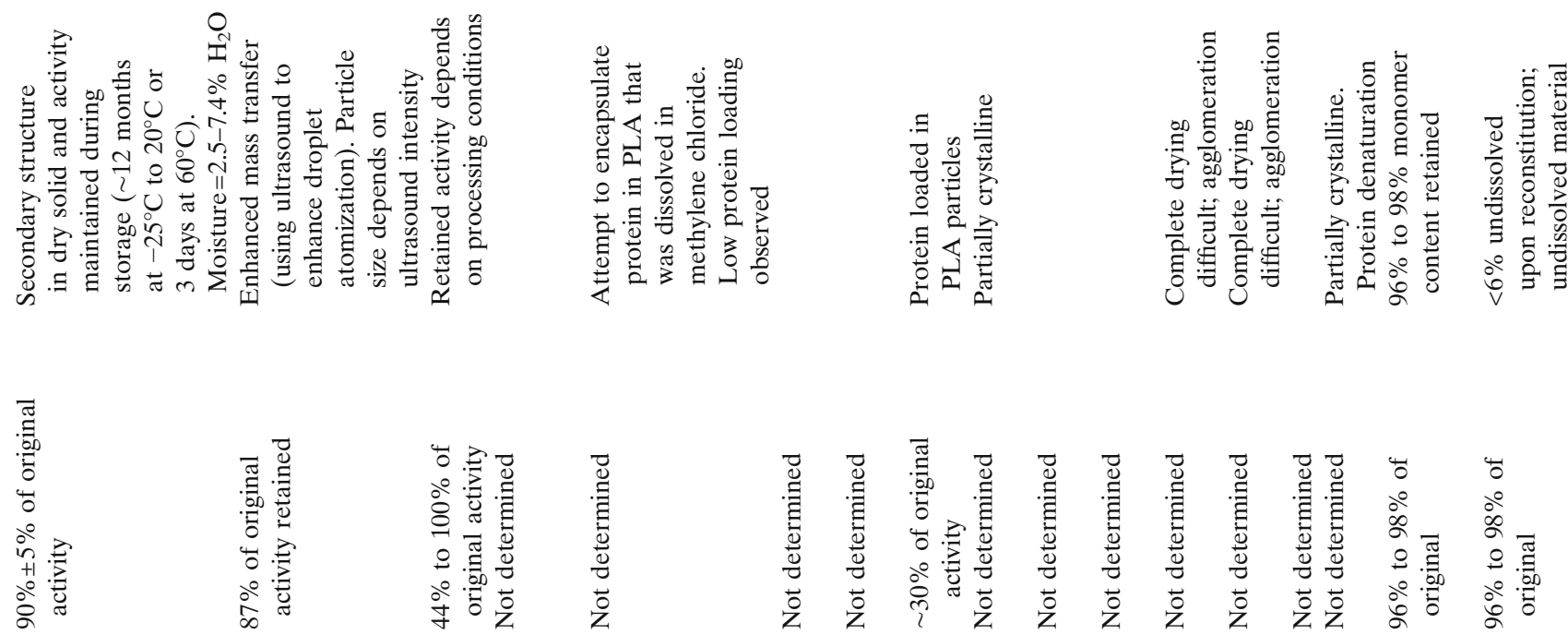

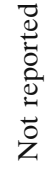

$\frac{0}{\stackrel{9}{9}}$

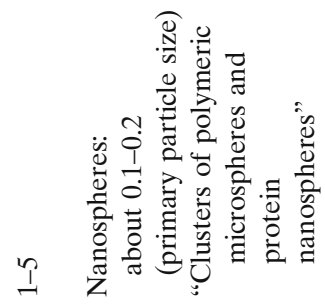

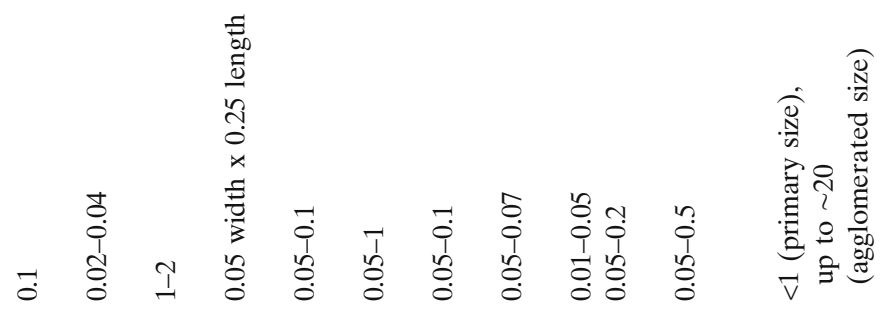

$\overbrace{}^{N}$

$\delta^{2} \delta^{2} \delta^{2}$

है है

䈉产

몽

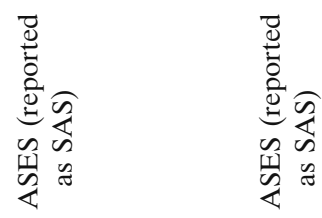

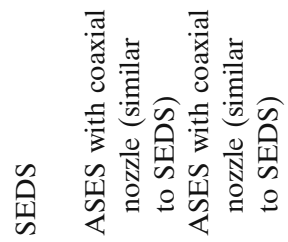

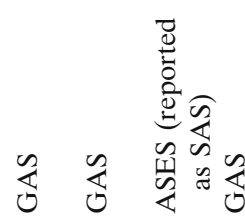

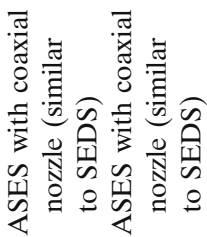

$\stackrel{\circ}{\sum^{n}}$

$\sum_{\substack{n \\ n}}^{n}$

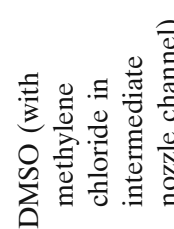

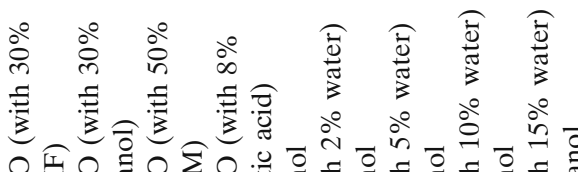

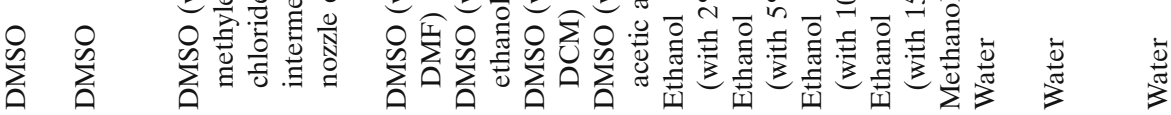

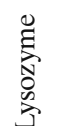

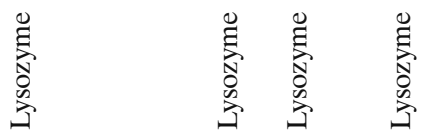

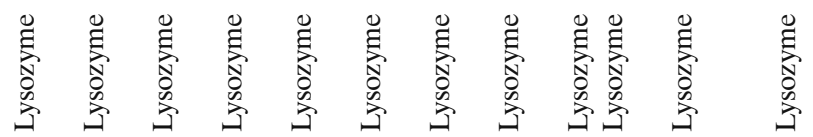




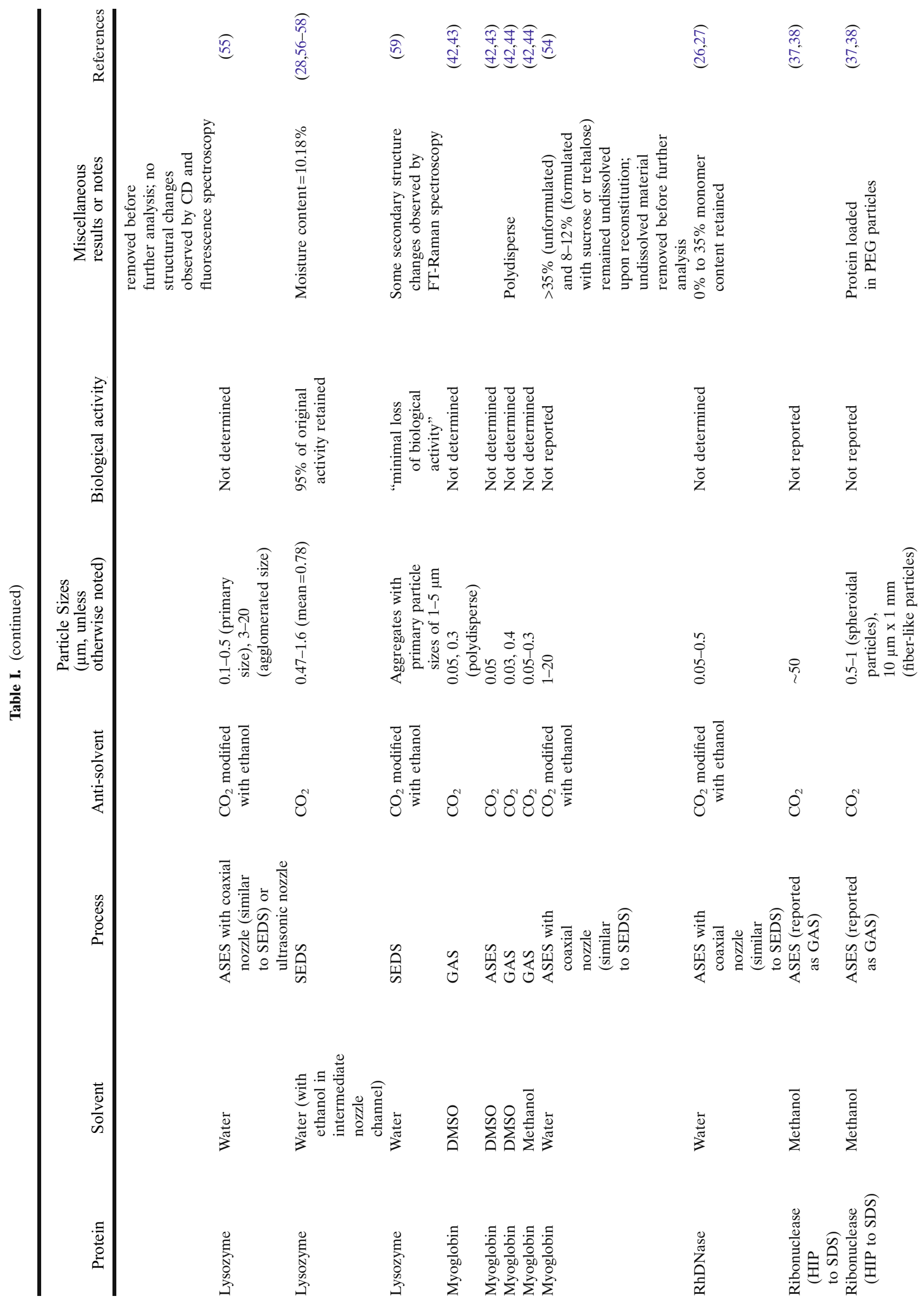




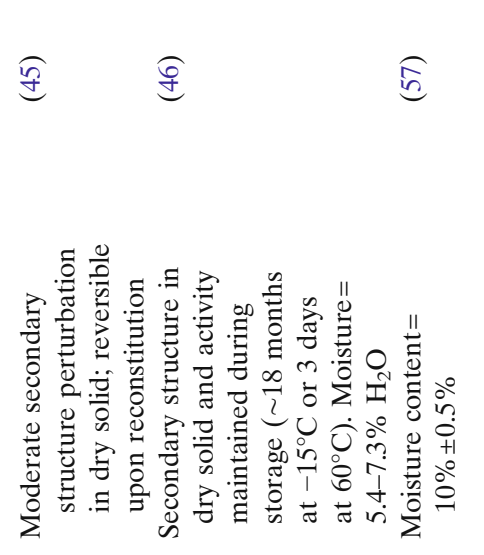

presented in the final sections. Anti-CD4 antibody is a Primatized ${ }^{\circledR}$ monoclonal antibody that has potential clinical application in autoimmune and inflammatory diseases (13). Alpha-1-antitrypsin (AAT or $\alpha_{1}$-AT), also known as $\alpha_{1}$ proteinase inhibitor (API or $\alpha_{1}$-PI), is a serine proteinase inhibitor in plasma, the primary physiological function of which is to protect the connective tissue of the lungs from excessive protease activity by neutrophil elastase $(14,15)$. AAT has been under clinical investigation (for both intravenous and aerosol pulmonary administration) as a therapeutic for $\alpha_{1}$-antitrypsin deficiency related emphysema and cystic fibrosis, diseases in which an imbalance of AAT relative to elastase is recognized $(15,16)$. Finally, trypsinogen was selected as a protein model for examining the effects of formulation conditions and CAN-BD processing on the biological activity of enzymes.

\section{OVERVIEW OF RAPID EXPANSION OF SUPERCRITICAL SOLUTIONS (RESS)}

The SCF method first used for particle preparation is RESS, rapid expansion of supercritical solutions. As reported by Jung and Perrut (5), the basic concept of RESS is actually more than a century old, starting with the work on metal salts by Hannay and Hogarth (17) in 1879, while the modern practice and applications to pharmaceuticals have been developed and patented over the past two decades. Particle formation by RESS is accomplished by dissolving the substance of interest in a supercritical fluid and then rapidly expanding the solution through a nozzle, thereby causing solute nucleation and particle growth. Successful application of this process is obviously limited to that category of substances soluble in a SCF; proteins are not appreciably soluble in pure carbon dioxide, liquid or supercritical. In fact, the anti-solvent processes discussed below use supercritical carbon dioxide $\left(\mathrm{scCO}_{2}\right)$ to precipitate proteins.

While a variety of supercritical fluids such as pentane, propane and nitrous oxide have been examined in particle formation processes, carbon dioxide is overwhelmingly the fluid of choice, particularly in the anti-solvent methods (5). It is relatively cheap, has readily accessible critical temperature $\left(31.1^{\circ} \mathrm{C}\right)$ and critical pressure $(7.38 \mathrm{MPa}$ or $1,070 \mathrm{psi})$, has relatively low toxicity, and is environmentally benign.

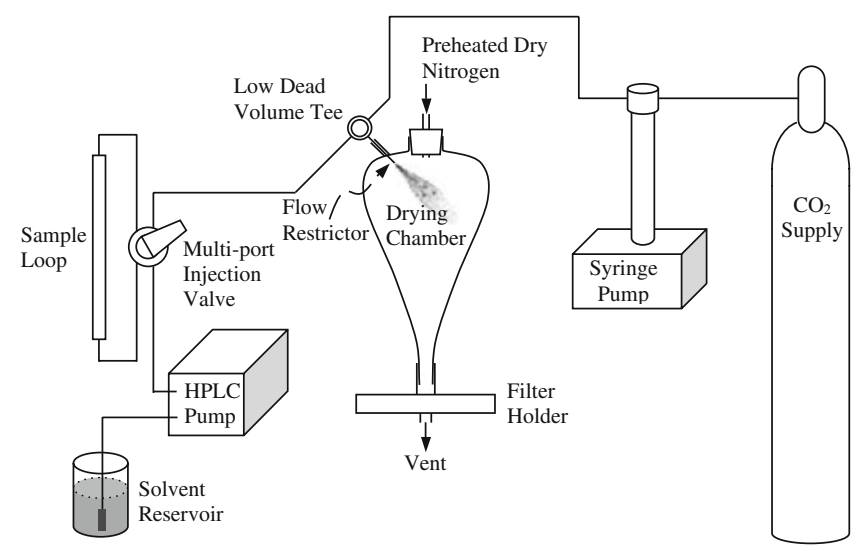

Fig. 1. Schematic diagram of a CAN-BD system. 


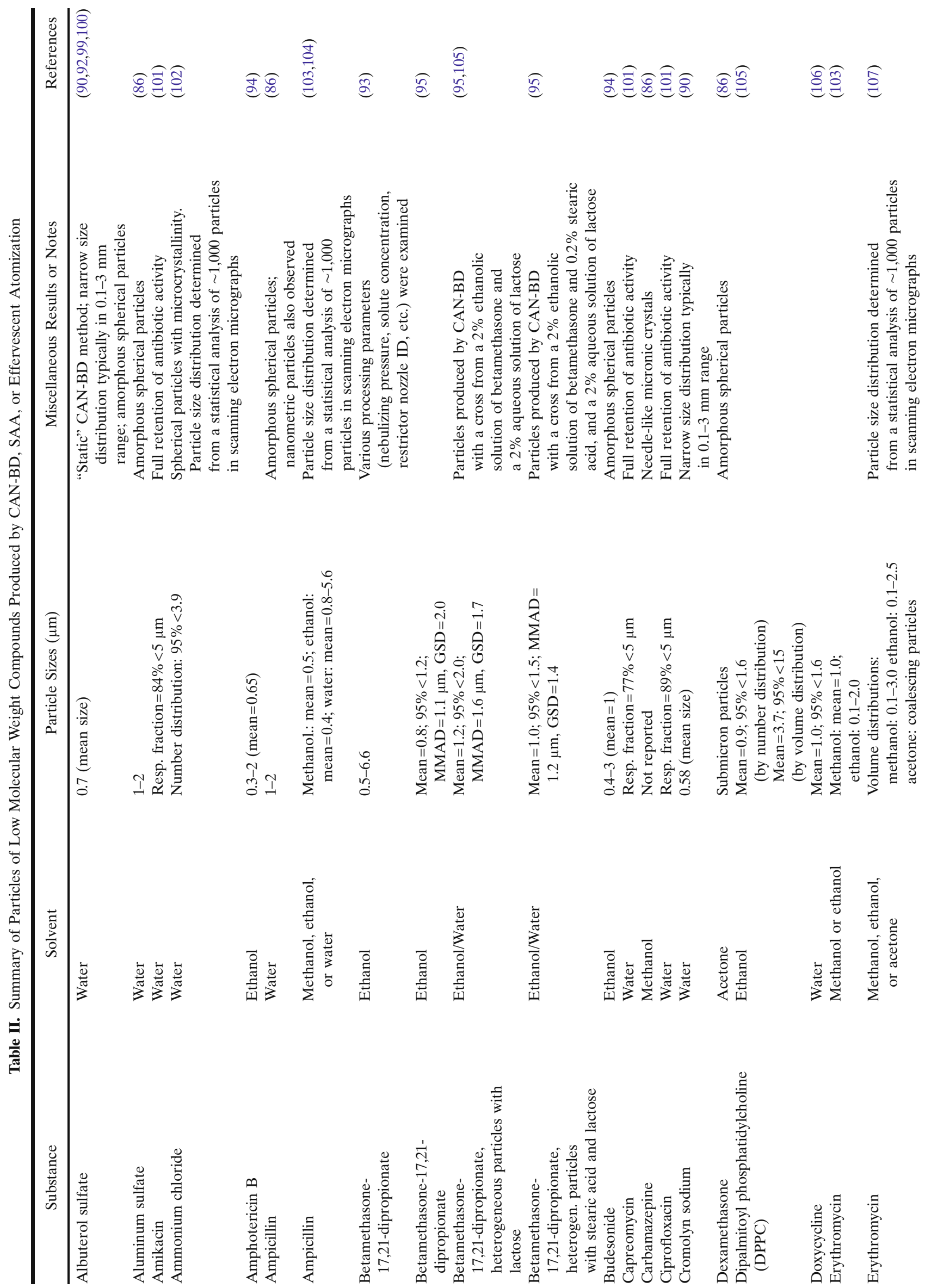




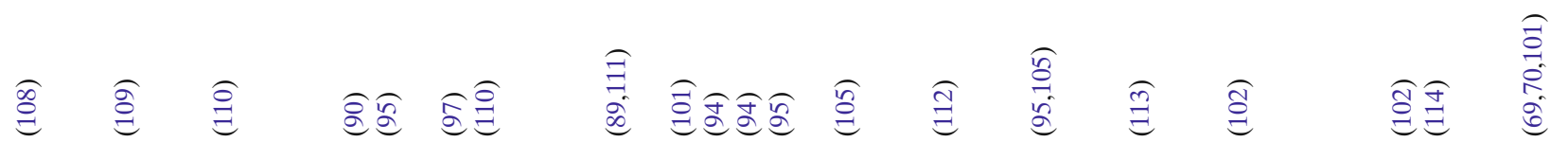

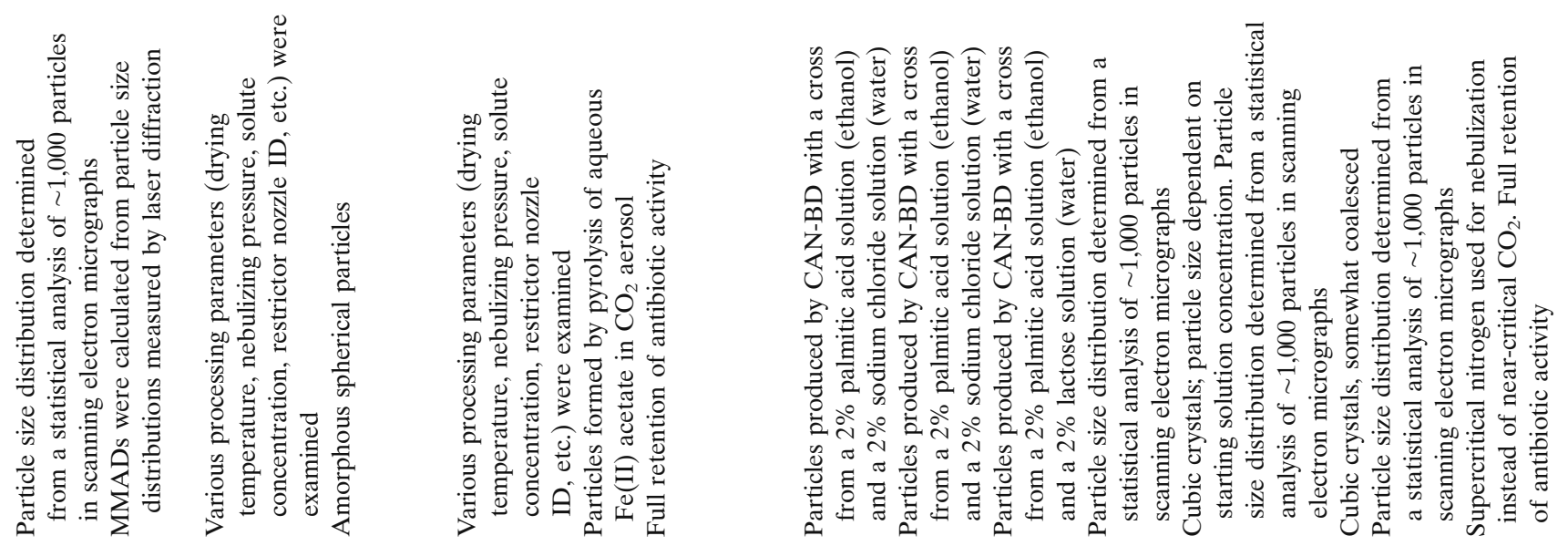

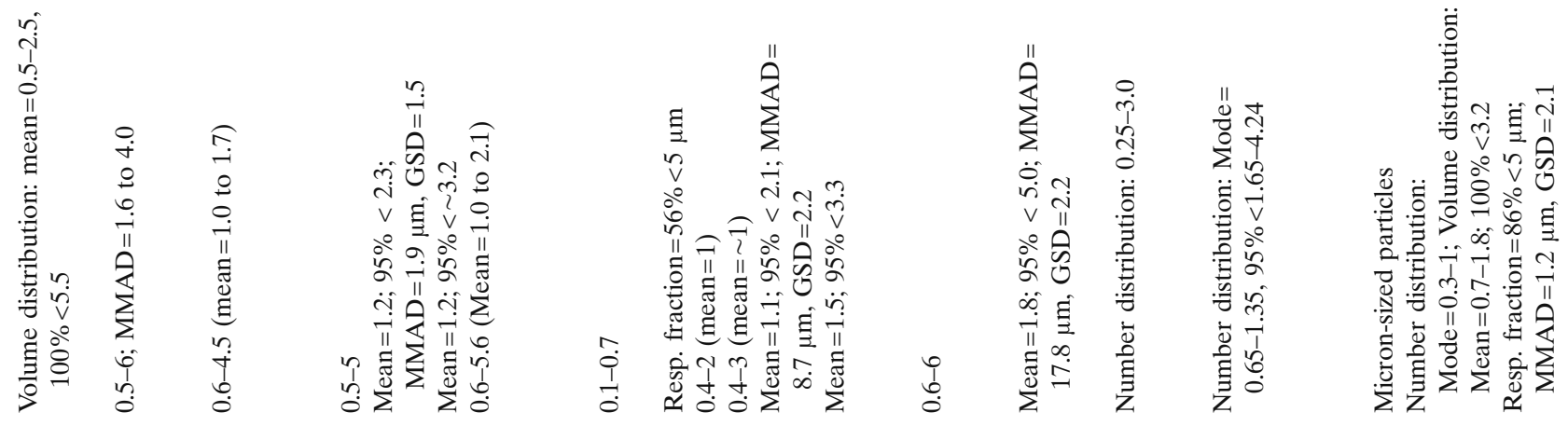

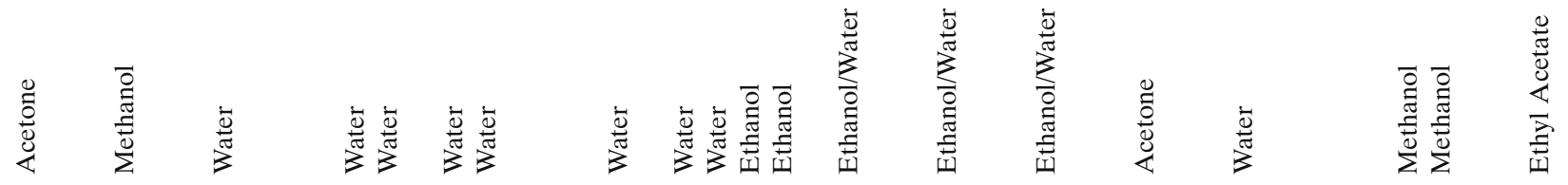

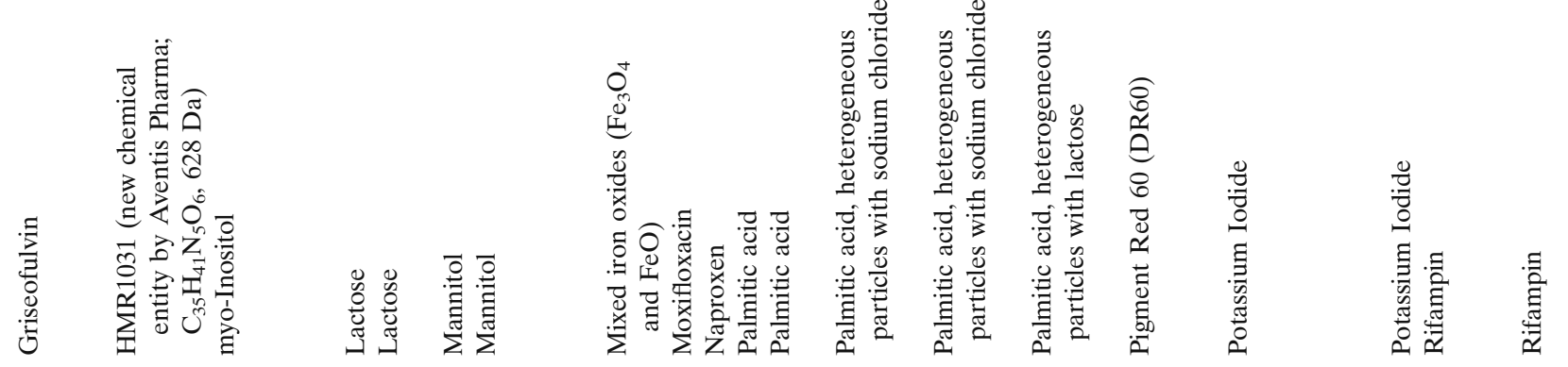




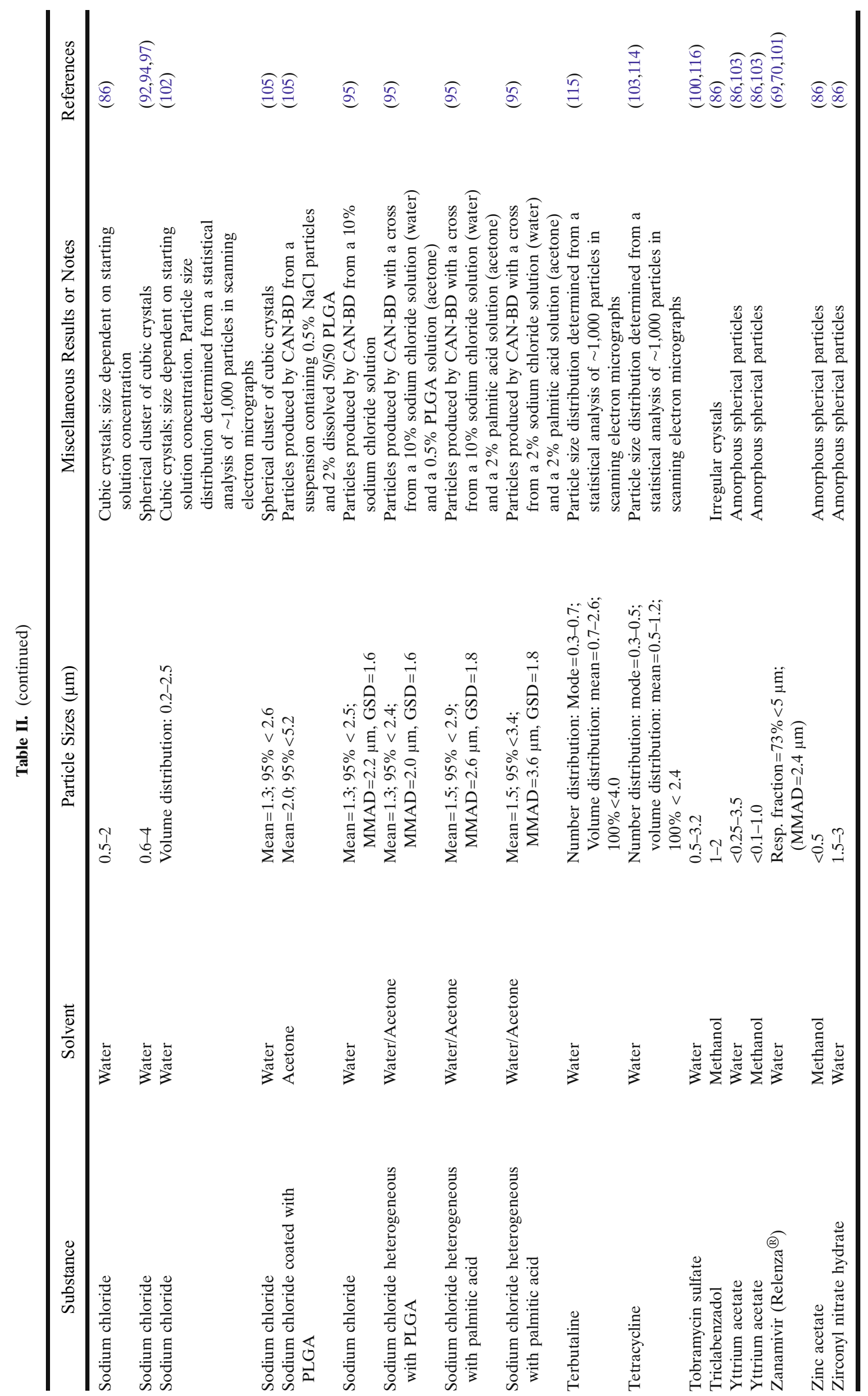




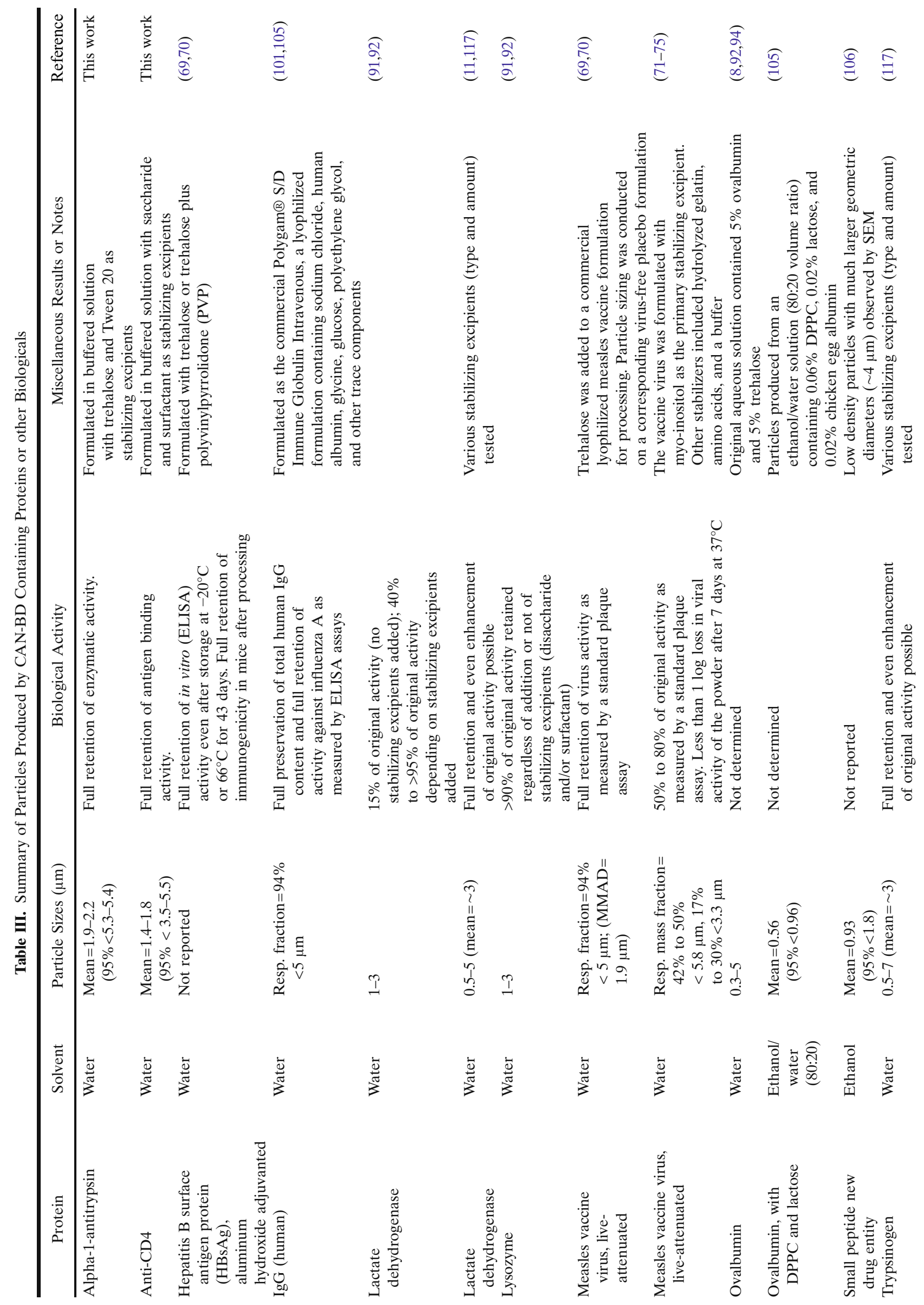




\section{政 PROCESSES}

While RESS is not applicable to the formation of protein particles, processes that take advantage of the ability of supercritical fluids or compressed gases to precipitate proteins have been investigated for this purpose. These processes all work on the same principle: the dense gas acts as an antisolvent when it dissolves in and expands a solvent containing the target solute(s), causing supersaturation and precipitation of the solute(s) in a high pressure chamber, usually operating at pressures $>1,200 \mathrm{psi}$. The solvent and supercritical or nearcritical fluid must be miscible. Unfortunately, the preferred solvent for most proteins, water, is very poorly miscible with dense $\mathrm{CO}_{2}$ : at $21^{\circ} \mathrm{C}$ and $1,200 \mathrm{psi}$, only $\sim 0.3$ mole $\%$ of water dissolves in $\mathrm{CO}_{2}$ and only $\sim 2.5$ mole $\%$ of $\mathrm{CO}_{2}$ dissolves in water (18). Therefore, the application of dense gas antisolvent processes is largely restricted to pharmaceuticals (such as lipophilic compounds) dissolvable in organic solvents that are miscible with the dense gas. Although the basic principle is the same in several processes, the various specific implementations of this principle have acquired different names and acronyms in the literature.

Gas anti-solvent (GAS) precipitation and Supercritical fluid anti-solvent (SAS) precipitation are essentially synonymous and refer specifically to the batch expansion of a solutecontaining solvent by a dense gas. Aerosol solvent extraction system (ASES) is a modification of GAS/SAS in which the solute-containing solvent is sprayed through an atomization nozzle into the compressed anti-solvent. Precipitation from compressed anti-solvent (PCA) is another designation found in the literature for what is essentially the ASES process. Solution enhanced dispersion by supercritical fluids (SEDS) is a refinement and modification of ASES in which a special nozzle with two (or three) coaxial channels is used to combine the SCF with the other solvents and spray the mixture into the same SCF. The three-channel nozzle allows aqueous solutions to be processed by SEDS by using an organic solvent, such as ethanol, that is miscible in both the aqueous solution and $\mathrm{scCO}_{2}$, to promote miscibility between $\mathrm{scCO}_{2}$ and water.

Anti-solvent processes have been applied to the preparation of protein particles with only limited success. Success is defined here as the formation of fine protein particles with mean aerodynamic diameter of less than $5 \mu \mathrm{m}$ and essentially full retention of biological activity. Table I summarizes the various proteins that have been processed into particles using anti-solvent methods. Particles of hydrophobic proteins such as insulin or generally robust proteins such as lysozyme that tolerate dissolution in or contact with organic solvents have been successfully prepared using GAS/SAS or related methods. Essentially full retention of activity has repeatedly been possible with lysozyme and insulin, which are relatively robust when compared with other proteins and peptides. For example, both of these proteins can be dried without stabilizing excipients and fully recover native structure and function after rehydration (19-21). In contrast, more labile proteins such as lactate dehydrogenase or Factor XIII are irreversibly denatured if they are subjected to drying without stabilizers (22-24). Success in stabilization and micronization is generally much more limited for other proteins and peptides. The literature review presented in Table I demon- 
strates that in the overwhelming majority of attempts to produce protein particles by anti-solvent techniques, postprocessing biological activity was either low or not determined or not reported.

Lysozyme is often chosen as a model protein for proof of concept testing of new techniques or processes because it is robust and is arguably the most investigated protein of all time for processing, formulation and drug delivery systems. This holds true in the developmental history of anti-solvent processes. Lysozyme is a good model to start with, but success with it far from guarantees success with any other protein, especially more labile ones. Before general claims of applicability to protein processing are made, a number of proteins should be tested, particularly ones that might be sensitive to stresses (such as organic solvent exposure and dehydration) encountered in the process.

It is well established in the published literature [see reviews by Carpenter et al. (60) and Wang (1)] that successful preparation of proteins in a dry solid form by lyophilization generally requires the addition of stabilizing excipients such as disaccharides (e.g., sucrose or trehalose) and/or surfactants (e.g., Tween 20 or 80). Careful pre-formulation studies are often undertaken in order to identify the optimal formulation: buffer type, amount, and $\mathrm{pH}$; disaccharide type and amount; surfactant type and amount; etc. The dense gas anti-solvent processes discussed here do not lend themselves to such careful formulation endeavors. Differential precipitation of the various excipients during expansion by the dense gas would complicate the formulation efforts. Carpenter et al. (60) make a strong case that long-term storage stability of proteins in a dry solid form generally hinges on whether or not native protein secondary structure is retained. In most of the cases in Table I, protein secondary structure was not considered nor investigated. Winters et al. (45) did examine secondary structure and found that there was minimal secondary structure perturbation in the dry solid due to ASES processing in the case of lysozyme, but moderate and appreciable perturbation in the cases of trypsin and insulin, respectively. Protein contact with or dissolution in the organic solvent(s) required for anti-solvent processing will usually significantly complicate the attempts to maintain native secondary structure, since such solvents are often protein denaturants. With a few exceptions, those investigators that did determine biological activity after processing did not, however, determine the long-term stability of the protein subjected to anti-solvent processing. Winters et al. (46) observed that the activity and secondary structure of lysozyme, trypsin and insulin in particles produced by ASES were maintained upon long-term storage at various temperatures relative to the activity and secondary structure determined immediately after processing (45). Thiering et al. (42,44), however, observed a $25 \%$ to $50 \%$ reduction in lysozyme activity upon storage over 3 months at $20^{\circ} \mathrm{C}$ of lysozyme particles produced by GAS. Despite the success by Winters $e t$ al. $(45,46)$, given the relatively poor track record or lack of data for proteins to date, particularly for proteins other than lysozyme, insulin and trypsin, one should not expect that dense gas anti-solvent processes will be broadly applicable to preparations of particles of stable protein formulations. The instability of many proteins and enzymes in contact with organic solvents (61) should lead one to conclude that processes requiring organic solvents will only be useful for a limited number of these biomolecules.

A few approaches to protein particle formation have involved dense gas processing of solid protein cakes or suspensions. Castor and Hong (62) obtained a patent for a process in which solid protein (e.g., from a lyophilized cake) is contacted with a supercritical fluid and then rapidly depressurized to achieve size reduction. Resulting size distributions were usually very broad with sizes typically ranging from tens of microns to several hundred microns. Although it was stated in the patent that retention of full activity was expected, no supporting activity data was presented. Young et al. (63) used a variation of ASES to encapsulate lysozyme in polymer microspheres. Lysozyme, spray-dried from aqueous solution to form 1-10 $\mu \mathrm{m}$ particles, was suspended in a solution of poly(lactic acid) (PLA) or poly (lactic acid-co-glycolic acid) (PGLA) in dichloromethane and then sprayed through a nozzle into a $\mathrm{CO}_{2}$ vapor phase over a $\mathrm{CO}_{2}$ liquid phase, leading to precipitation of the polymer and encapsulation of the lysozyme. Particle sizes were typically 5 to $60 \mu \mathrm{m}$. The biological activity of the processed lysozyme was not reported. Mishima et al. (64) used a variation of RESS to encapsulate lysozyme and lipase into various polymers. Solid protein was suspended in $\mathrm{scCO}_{2}$ containing a cosolvent (e.g., ethanol) and dissolved polymer (e.g., polyethylene glycol (PEG)) and then rapidly expanded through a capillary nozzle to atmospheric conditions. Particles containing encapsulated protein with primary diameters ranging from 8 to $62 \mu \mathrm{m}$ were reported. No biological activity data were reported. In more recent reports (65-68), dry particles (produced by milling and sieving of lyophilized material) or dry microcrystals of several proteins and enzymes have been coated or encapsulated using SCF processes; full or very good retention of activity was reported for these proteins.

\section{CO $_{2}$-ASSISTED NEBULIZATION WITH A BUBBLE DRYER $^{\circledR}$ (CAN-BD)}

CAN-BD is a process patented by Sievers et al. (8-12). This invention covers two versions of the process, static and dynamic. The static version involves the pre-mixing of $\mathrm{scCO}_{2}$ and a solution containing a solute of interest at a pressure higher than the critical pressure of $\mathrm{CO}_{2}$. After equilibrium is established or approached, the mixture in a high pressure chamber is allowed to expand to atmospheric pressure through a flow restrictor (or a capillary tube) by expansion into a drying chamber.

The dynamic version involves continuous intimate mixing of a solution containing a solute of interest and $\mathrm{scCO}_{2}$ or near-critical $\mathrm{CO}_{2}$. In one version of this process, the two fluid streams become intimately mixed in a low dead volume tee and are then expanded through a flow restrictor to atmospheric pressure, where the plume of microbubbles and microdroplets are rapidly dried. This dynamic version of CAN-BD has been consistently, repeatedly and broadly successful in preparing protein particles that are usually stable, active and in the size range suitable for pulmonary delivery. This success has been achieved because the aqueous solution or suspension containing a protein or vaccine virus can be formulated to contain the appropriate stabilizers. 


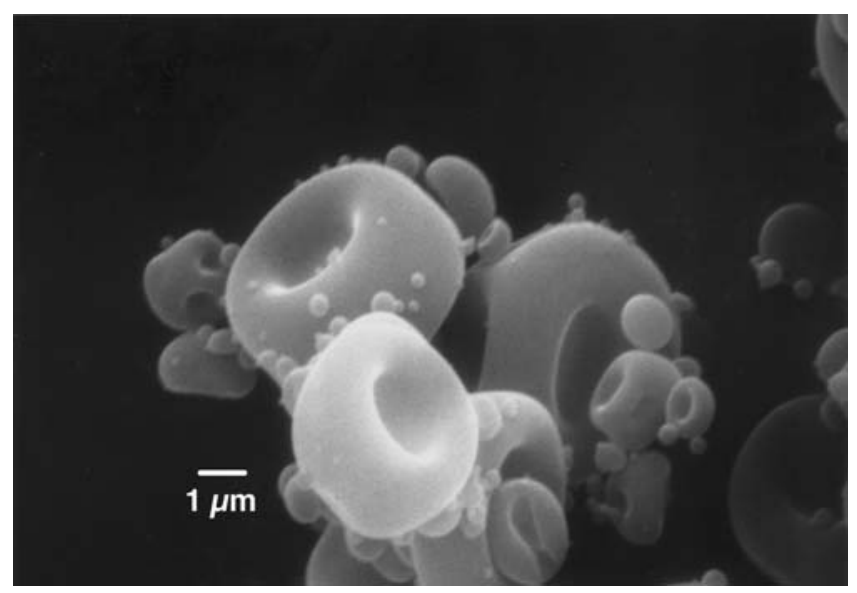

Fig. 2. SEM image of particles of anti-CD4 antibody produced by CAN-BD at $50^{\circ} \mathrm{C}$ (Run A). SEM images obtained as described elsewhere (91).

Recently, the CAN-BD process has been used to produce dry powders of live-attenuated measles vaccine virus (EdmonstonZagreb) with good mechanical yield and with retention of viral activity as measured by a plaque forming unit assay that is comparable to commercial lyophilization (69-75). CAN-BD has also been used to dry siRNA nucleotides (71). Depending on formulation and laboratory processing conditions, typical lab scale yields range between $50 \%$ and $90 \%$. In traditional spray drying, yield usually increases with scale, and the same may be realized for CAN-BD, in which droplet drying and particle collection is similar to traditional spray drying.

In papers by Abdul-Fattah et al. $(76,77)$ and patent applications by Truong-Le et al. (78-81), drying process methods are described that are similar to the CAN-BD process patents (8-12). Truong-Le et al. called this process, which uses compressed fluids of carbon dioxide, nitrogen, helium, or argon, "high pressure effervescent atomization" or "high pressure spray drying". Both carbon dioxide and nitrogen were used at similar temperatures and pressures in the 1997 patent (8). In some of the examples given by Truong-Le et al. (78-81), particles of stable live attenuated B/ Harbin influenza virus can be stored with only about one log loss of activity over one year at $25^{\circ} \mathrm{C}$. High pressure spray drying was also used to prepare dry powders of an $\mathrm{IgG}$

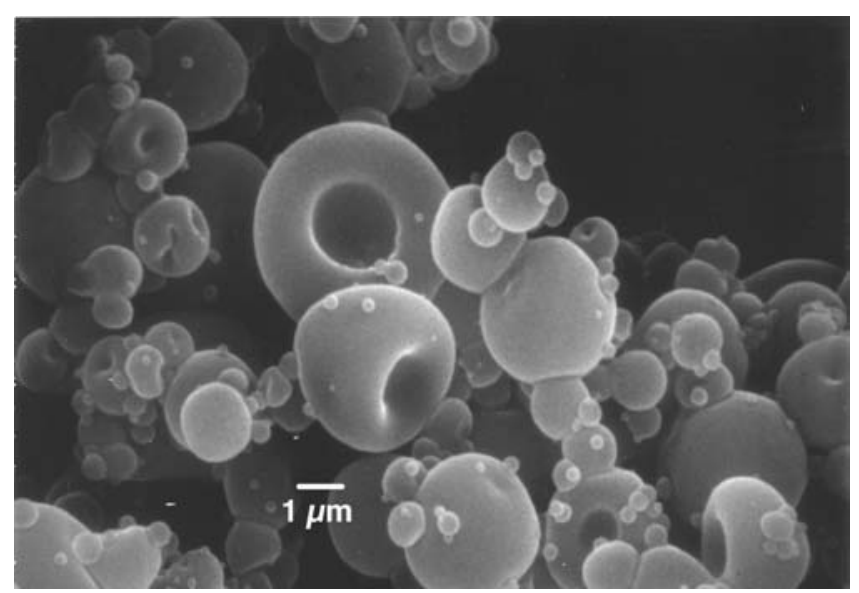

Fig. 3. SEM image of particles of anti-CD4 antibody produced by CAN-BD at about $30^{\circ} \mathrm{C}$ (Run B).

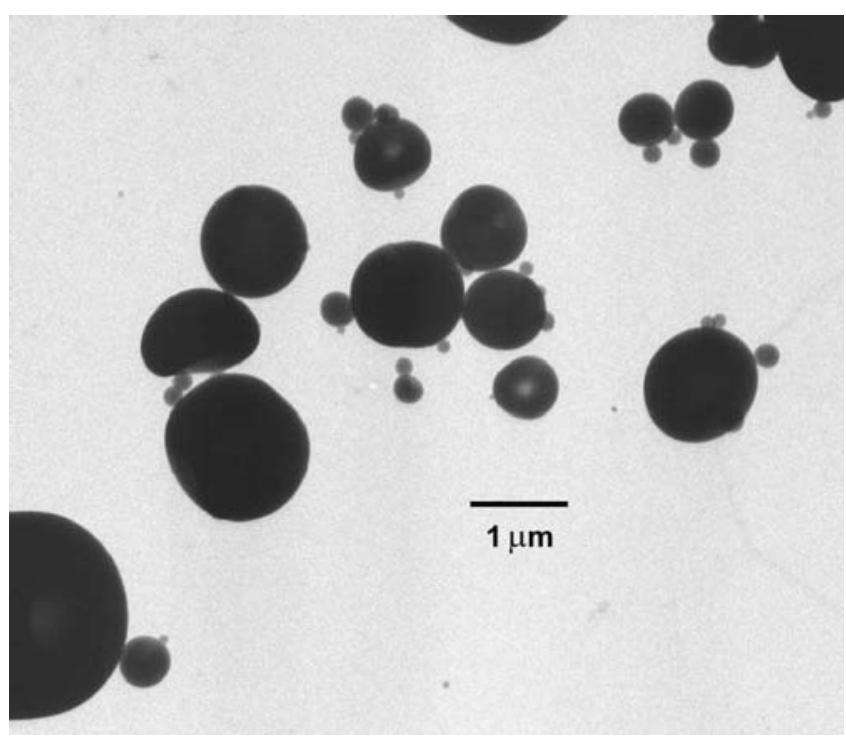

Fig. 4. TEM image of particles of anti-CD4 antibody produced by CAN-BD at $50^{\circ} \mathrm{C}$ (Run A). Particles were physically adhered to glow-discharged, carbon-coated, Formvar-coated copper grids by gently touching the activated side of the grid to the powder and then were visualized using a Philips CM 10 microscope operated at an accelerating voltage of $80 \mathrm{kV}$.

monoclonal antibody and a live attenuated virus vaccine of a parainfluenza strain $(76,77)$. The spray dried vaccine preparation was less stable compared to that from foam drying but more stable than that obtained by freeze drying. Additionally, in a recently issued patent by Shekunov et al. (82) and in patent applications by Truong-Le et al. $(83,84)$, spray freeze drying methods are described that employ the nebulization method patented earlier $(8,9,11)$, combined with a freeze drying or lyophilization step. Shekunov et al. $(82,85)$ showed that $>80 \%$ of the biological activity of trypsinogen (formulated with trehalose) could be retained using their modification of the CAN-BD process. B/Harbin influenza virus processed with the Truong-Le et al. $(83,84)$ spray freeze drying method was reported to have only lost about one log

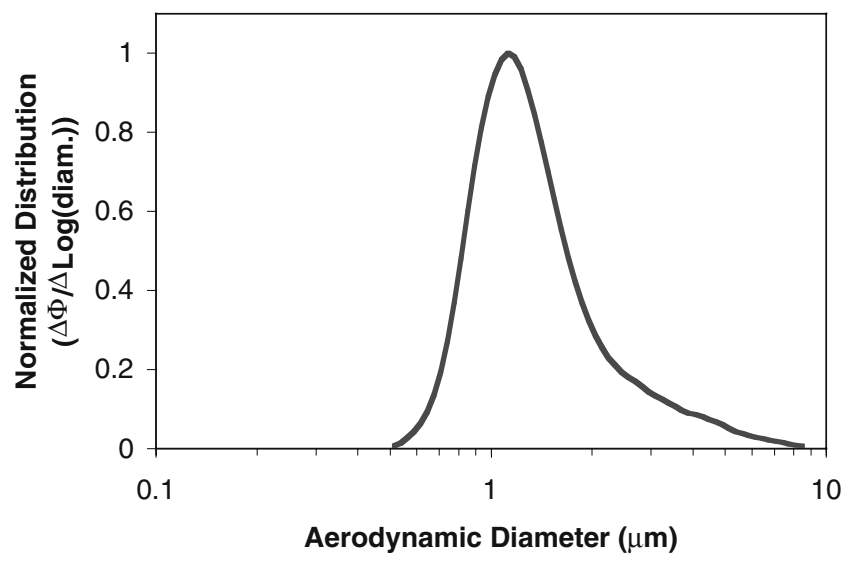

Fig. 5. Aerodynamic size distribution of particles of anti-CD4 antibody produced by $\mathrm{CAN}-\mathrm{BD}$ at $50^{\circ} \mathrm{C}$ (Run A). Mean size $=$ $1.4 \mu \mathrm{m}$ with $95 \%$ of the particles less than $3.5 \mu \mathrm{m}$. Size distributions for the case studies presented in this manuscript were weighted by number. Particle sizes were measured using a TSI Model 3225 Aerosizer ${ }^{\circledR}$ DSP, which employs a laser-detected time of flight technique. 


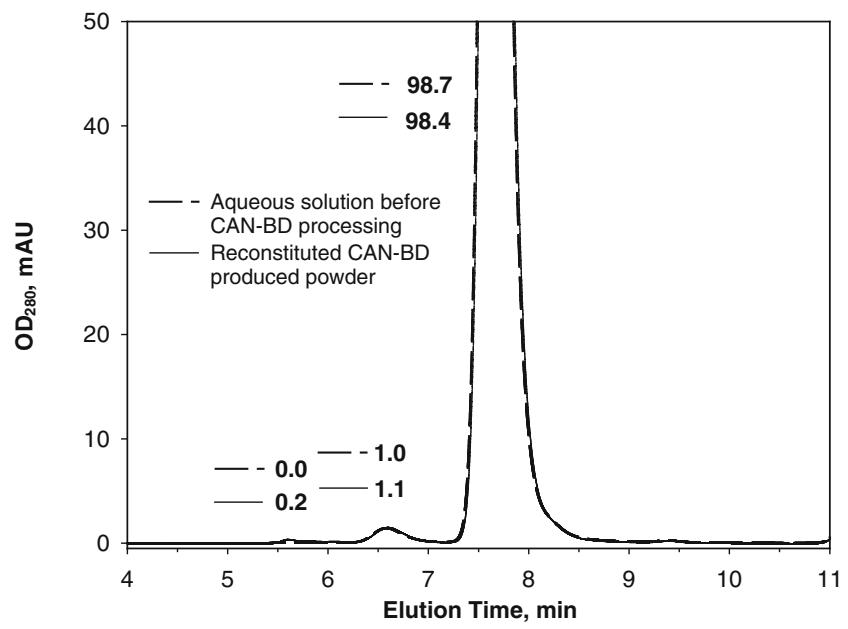

Fig. 6. Size-exclusion chromatograms of rehydrated dry powders of anti-CD4 antibody produced by CAN-BD at $50^{\circ} \mathrm{C}$ (Run A) compared to the starting material. Numbers above or next to peaks refer to their area percents. Size-exclusion HPLC was performed using an HPLC system (Agilent Technology 1100 series) equipped with a TSK-Gel G3000SWXL column (Tosoh Biosep LLC, Pennsylvania, USA), using a phosphate based buffer for elution.

of activity over 13 months at $25^{\circ} \mathrm{C}$ or 67 days at $37^{\circ} \mathrm{C}$ for certain formulations. One variant of the CAN-BD process has also been referred to by Reverchon et al. (86-88) as supercritical-assisted atomization (SAA) in the published literature. In SAA, carbon dioxide is intimately mixed with the solution to be dried in a large high pressure chamber containing packing that provides a large surface area, to achieve effervescent atomization.

\section{Principles of CAN-BD}

Unlike the anti-solvent processes, CAN-BD does not employ dense gases to achieve precipitation by solubility reduction of the solute(s) to be micronized. Rather they are used to enhance or facilitate the nebulization or aerosolization of a liquid solution, which is then rapidly dried to form particles by solvent removal. Organic or aqueous solutions are both readily processed by CAN-BD, although neither solvent type needs to be present for the processing of the other. CAN-BD is broadly applicable to the processing of aqueous protein solutions and therefore lends itself readily to studies undertaken to create dry solid formulations optimized for protein storage stability and retention of biological activity, and to develop such protein particles with morphology and size suitable for pulmonary administration.

Table IV. Percentage of Binding Activity of Anti-CD4 Antibody to its Antigen as Measured by a Standard ELISA Method

\begin{tabular}{lc}
\hline Sample description & $\%$ binding activity \pm SD \\
\hline Bulk solution & $106 \pm 6$ \\
CAN-BD & $91 \pm 10$ \\
Lyophilized & $95 \pm 7$ \\
\hline
\end{tabular}

A goat anti-human IgG HRP conjugate and ABTS were used to detect the bound antibodies on the soluble CD4 antigen-coated plate

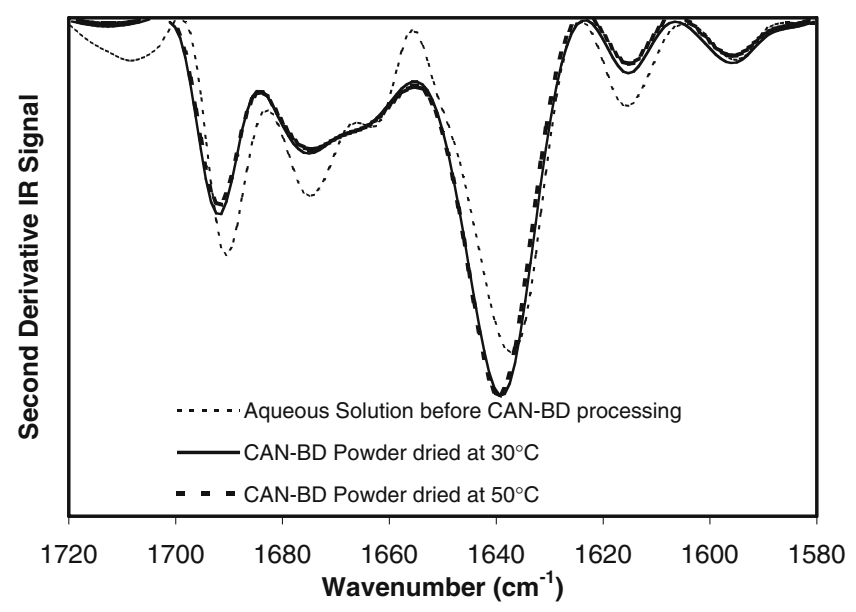

Fig. 7. Second-derivative infrared spectroscopy of unprocessed bulk solution and powders of anti-CD4 antibody produced by CAN-BD at $30^{\circ} \mathrm{C}$ (Run B) and $50^{\circ} \mathrm{C}$ (Run A). IR spectra were collected and analyzed according to the methods described by Dong et al. (119-121).

The principles of the CAN-BD process and the experimental setup have been previously described elsewhere (8995). They are here briefly described again. Figure 1 is a schematic diagram of a typical CAN-BD system. A liquid solution (organic or aqueous), typically containing $1 \%$ to $10 \%$ total dissolved solids, is brought into intimate contact with supercritical or near-critical $\mathrm{CO}_{2}$ (usually at 1,200 to 1,500 psi and $20^{\circ} \mathrm{C}$ to $35^{\circ} \mathrm{C}$, although a wide variety of conditions can be used) in a low dead volume tee. The resulting emulsion or solution mixture is rapidly expanded to near atmospheric pressure through a capillary flow restrictor, which is usually fused silica, stainless steel or PEEK with an inner diameter of 50 to $175 \mu \mathrm{m}$ and a length of $\sim 10 \mathrm{~cm}$. Upon expansion, the emulsion or solution forms a dense aerosol consisting of microdroplets and microbubbles. The aerosol is formed primarily due to the sudden physical dispersion of the liquid solution caused by the rapid expansion of compressed $\mathrm{CO}_{2}$. Further break up of the microdroplets occurs due to the sudden release of any $\mathrm{CO}_{2}$ that became dissolved in the liquid solution during intimate contact in the tee. At 1,000 to 2,000 psi, the solubility of $\mathrm{CO}_{2}$ in water is about 2 to 2.5 mole $\%$ (18). The dense aerosol is delivered into a drying chamber (maintained at or near atmospheric pressure), into which preheated air or nitrogen gas is also delivered so as to maintain the chamber at a desired average drying temperature (typically $25^{\circ} \mathrm{C}$ to $65^{\circ} \mathrm{C}$ when processing aqueous protein solutions). Drying of an aerosol droplet is very fast. Adler and Lee (96) calculated that the total drying time in a Buchi spray-dryer $\left(T_{\text {inlet }}=150^{\circ} \mathrm{C}, T_{\text {outlet }}=95^{\circ} \mathrm{C}\right)$ was less than $2 \mathrm{~ms}$ for a $8.6 \mu \mathrm{m}$ droplet containing $10 \%(w / w)$ trehalose. In CAN-BD, the average residence time of a droplet/dry particle in the drying chamber has been estimated from chamber volume and flow rate calculations to be a few seconds (94). It should be noted that the droplet drying time will be shorter than the residence time. Microbubbles should dry even faster than microdroplets with the same diameter.

In drying some substances by CAN-BD, hollow dry particles are formed. Dry particles are collected on a filter membrane, with pore sizes between 0.2 and $0.45 \mu \mathrm{m}$, located 
Table V. Summary of Results for Powders of Anti-CD4 Antibody Produced by CAN-BD

\begin{tabular}{lrrrr}
\hline & & \multicolumn{2}{c}{ Particle size $(\mu \mathrm{m})$} & \\
\cline { 3 - 4 } Run & Drying temp. $\left({ }^{\circ} \mathrm{C}\right)$ & Mean & 95\% less than & 3.5 \\
Water content $(\%)$ \\
\hline A & 50 & 1.4 & 5.5 & 2.0 \\
B & 25 to 30 & 1.5 & 3.9 & 1.7 \\
C & 50 & 1.5 & 4.9 & 1.3 \\
D & 50 & 1.8 & 4.0 & 1.5 \\
E & 50 & 1.5 & 1.4 \\
\hline
\end{tabular}

Aerodynamic particle size was measured as in Fig. 5. The powders were stored for one to several weeks in a vacuum chamber over calcium sulfate desiccant before their water content was determined using a methanol extraction method and a Denver Instruments Model 260 Titration Controller with a Model 275KF Coulometric Karl Fischer Titrator

at the outlet of the drying chamber. CAN-BD can be operated as either a batch, semi-continuous, or continuous process. Typical flow rates on a lab-scale are 0.3 to $0.6 \mathrm{ml} / \mathrm{min}$ of liquid solution and 1 to $3 \mathrm{ml} / \mathrm{min}$ of dense $\mathrm{CO}_{2}$. We have successfully scaled up CAN-BD to process up to $20 \mathrm{ml} / \mathrm{min}$ of liquid solution (97), and have more recently used flow rates as high as $30 \mathrm{ml} / \mathrm{min}$, which is commercial production scale for high value pharmaceutical products (98).

Organic solvents that are compatible with liquid carbon dioxide can be substituted in part or totally for water. Examples that the authors have used include ethanol, methanol, acetone, ethyl acetate and various mixtures of solvents, surfactants, buffers, stabilizers and other excipients. The solvent choice depends on the solubility and stability of the pharmaceutical to be micronized, and on the desired morphology and mean size of the particles.

\section{Review of Successful Applications of CAN-BD}

Application of the CAN-BD process to produce fine particles of a variety of substances dissolved in a variety of solvents has been broadly successful. Table II summarizes the application of CAN-BD to small-molecule substances such as salts, sugars and low-molecular weight pharmaceutical products. Particles in the respirable size range of 1 to $5 \mu \mathrm{m}$ were

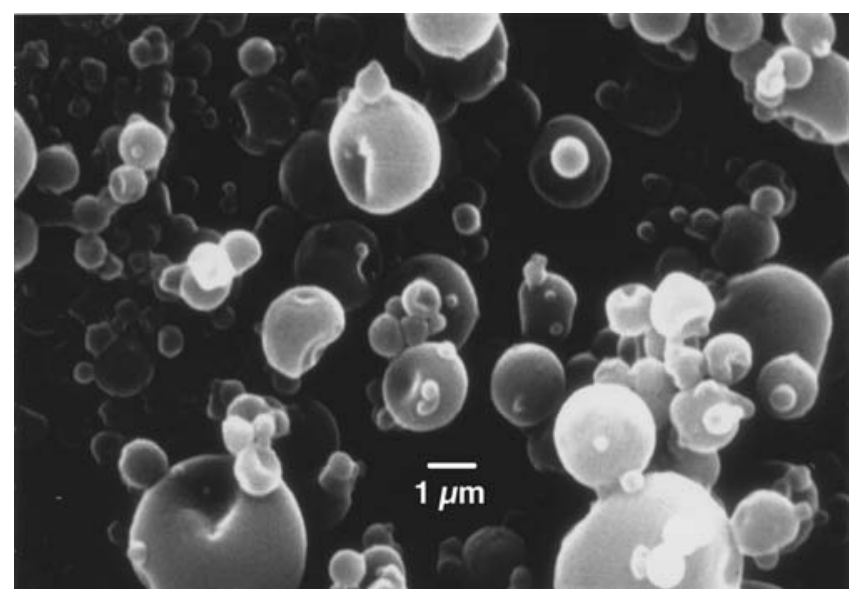

Fig. 8. SEM image of AAT particles produced by CAN-BD at $40^{\circ} \mathrm{C}$ from an aqueous solution containing AAT and trehalose (3 to 5 mass ratio) in $0.1 \mathrm{M}$ sodium phosphate, $\mathrm{pH} 7.0$ buffer with $0.1 \%$ Tween 20 . consistently produced. The CAN-BD process has also been applied to the preparation of protein particles with broad success. Table III summarizes the examples of CAN-BD in protein processing to form stable active powders. To achieve the desired protein stability and retention of biological activity, addition of $\mathrm{pH}$ buffers and appropriate stabilizing excipients such as disaccharide sugars (e.g., sucrose or trehalose) or surfactants (e.g., Tween 20 or Tween 80) are usually required. However, addition of these solution components does not pose any extra processing difficulties for CANBD. Full retention of biological activity is readily and repeatedly observed for proteins appropriately formulated. An interesting example of a protein vaccine that has shown full retention of activity after CAN-BD processing, as indicated in both in vitro (ELISA) and in vivo (mice) tests, is the hepatitis B surface antigen (HBsAg) $(69,70)$. As mentioned above, CAN-BD has been recently used to prepare fine dry powders of live attenuated measles vaccine virus (69-75). For a myo-inositol based formulation under development as an inhalable dry powder vaccine, it was determined that $72 \% \pm 18 \% \mathrm{SD}(n=8)$ of the viral activity was preserved through CAN-BD processing $(74,75)$. This compares favorably with freeze drying of the commercial sorbitol based measles vaccine formulation, in which retention of activity is on the order of $50 \%$ to $60 \%$. In addition, the CAN-BD prepared powder formulation passed the World Health Organization stability criterion of less than one $\log$ loss (or less than $90 \%$ loss) after 7 days of storage at $37^{\circ} \mathrm{C}$. Specifically, the myo-inositol based formulation retained $20 \% \pm 9 \%$ SD $(n=4)$ of the viral activity after 7 days at $37^{\circ} \mathrm{C}$. Aerodynamic diameters by cascade impaction were determined to be $45 \%$ to $50 \%<5.8 \mu \mathrm{m}$ and $\sim 20 \%<3.3 \mu \mathrm{m}$. In vivo viral replication was demonstrated by the observation by polymerase chain reaction (PCR) assay of measles vaccine virus nucleoproteins in the lungs of Cotton rats 7 to 14 days after the rats were allowed to inhale an aerosolized powder of the myo-inositol based CAN-BD powder formulation (75).

Under certain formulation conditions, apparent enhancement of the enzymatic activity of lactate dehydrogenase (LDH) and trypsinogen has been observed $(11,117)$. This indicates that treatment with supercritical or near-critical $\mathrm{CO}_{2}$ can possibly refold the protein molecules in the original stock solution that are denatured or in a subactive folded conformation to a native and active structure. Independent investigators have reported similar results. Giessauf and Gamse (118) reported increases in the enzymatic activity of porcine 
Table VI. Summary of Trypsinogen-Sugar Particles Generated by CAN-BD

\begin{tabular}{|c|c|c|c|c|c|}
\hline \multicolumn{2}{|c|}{ Composition by weight percent Aqueous Solution (dry solid) } & \multicolumn{2}{|c|}{ Trehalose Particle size $(\mu \mathrm{m})$} & \multicolumn{2}{|c|}{ Sucrose Particle size $(\mu \mathrm{m})$} \\
\hline Trypsinogen & Sugar $^{\mathrm{a}}$ & Mean & $<95 \%$ & Mean & $<95 \%$ \\
\hline $1(100)$ & 0 & $0.86^{\mathrm{b}}$ & $1.57^{b}$ & & \\
\hline $1(80)$ & $0.25(20)$ & 0.86 & 1.47 & 0.86 & 1.57 \\
\hline $1(67)$ & $0.5(33)$ & 0.89 & 1.53 & 0.87 & 1.47 \\
\hline $1(50)$ & $1(50)$ & 0.90 & 1.56 & 0.87 & 1.56 \\
\hline $1(33)$ & $2(67)$ & 0.93 & 1.75 & 1.02 & 1.85 \\
\hline $1(20)$ & $4(80)$ & 1.02 & 2.06 & 1.06 & 1.93 \\
\hline $1(11)$ & $8(89)$ & 1.17 & 2.47 & 1.33 & 2.86 \\
\hline 0 & $10(100)$ & 1.34 & 2.58 & 1.43 & 2.88 \\
\hline
\end{tabular}

${ }^{a}$ The sugar used as an excipient was either sucrose or trehalose.

${ }^{b}$ These particles contained no sugar, only trypsinogen.

pancreatic lipase as high as $860 \%$ upon treatment with supercritical carbon dioxide, although they treated damp powders by hourly pressurization and depressurization cycling with supercritical carbon dioxide, while our studies were by CAN-BD of aqueous solutions, followed by dissolution of the dried LDH or trypsinogen for enzymatic activity assays.

\section{CAN-BD Case Studies}

The CAN-BD process described above was used to obtain fine dry powders of anti-CD4 antibody, AAT and trypsinogen. An aqueous solution containing the given protein with excipient(s) was delivered to one inlet of a low dead volume mixing tee using an HPLC pump set at a constant flow rate, typically 0.3 to $0.5 \mathrm{ml} / \mathrm{min}$. Supercritical or near-critical $\mathrm{CO}_{2}$ (typically at room temperature and 1,200 psi) was delivered to the other inlet of the tee using an ISCO Model 260D syringe pump. The resulting fine emulsion of liquid near-critical $\mathrm{CO}_{2}$ and aqueous protein solution was then rapidly expanded to near atmospheric pressure through a fused silica capillary tube (9 to $10 \mathrm{~cm}$ length, $74 \mu \mathrm{m}$ I.D.) into a glass drying chamber (1 to 2.51 ) to form a very fine aerosol of aqueous droplets. Preheated nitrogen was passed through the drying chamber at 15 to $30 \mathrm{l} /$ min to maintain the average temperature at a selected set

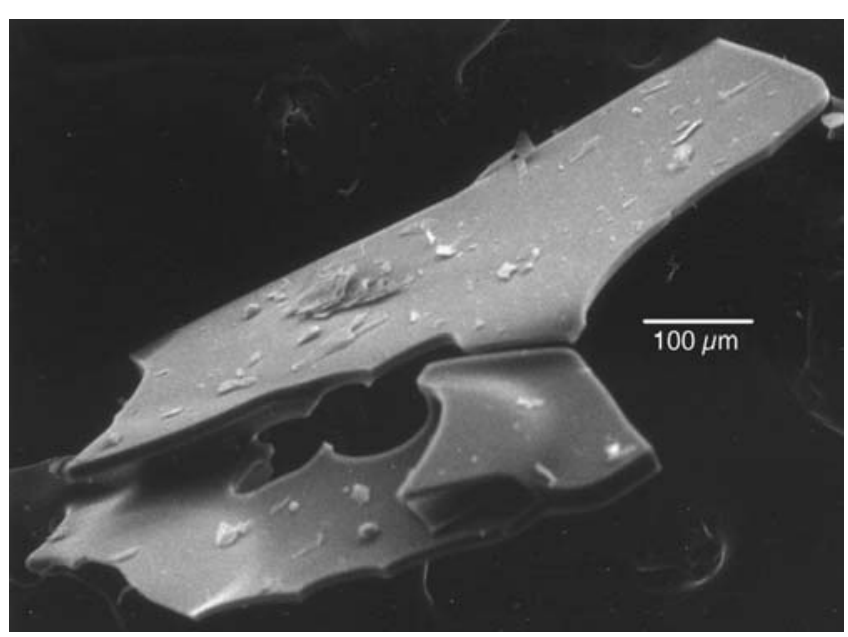

Fig. 9. SEM image of commercial as-received lyophilized trypsinogen. point (usually between $25^{\circ} \mathrm{C}$ and $65^{\circ} \mathrm{C}$ ), thereby drying the aerosol to form dry particles, which were collected on a filter ( 0.2 or $0.45 \mu \mathrm{m}$ mixed cellulose ester, $142 \mathrm{~mm}$ diameter, Advantec MFS, Inc., Dublin, CA) located at the exit of the drying chamber.

\section{Anti-CD4 Antibody}

Using the CAN-BD process, we have successfully produced fine, dry powders of anti-CD4 antibody, a Primatized monoclonal antibody with potential clinical value in treating rheumatoid arthritis and other diseases. Anti-CD4 antibody was expressed in $\mathrm{CHO}$ cells and purified by several chromatographic steps to homogeneity. The material was formulated in a proprietary buffered solution containing saccharide and surfactant as stabilizing excipients and was used as provided by Biogen Idec Inc. (San Diego, CA).

Figure 2 (91) is a representative SEM image of particles produced at $50^{\circ} \mathrm{C}$. The particles display dimpled "ping-pong ball" morphology. Figure 3 is an SEM image of anti-CD4 antibody particles dried at about $30^{\circ} \mathrm{C}$ and displays the same morphology, although the dimple effect is somewhat less pronounced. Such morphology was characteristic of all antiCD4 antibody powders that we generated by CAN-BD and suggests that the particles are hollow, or at least began as

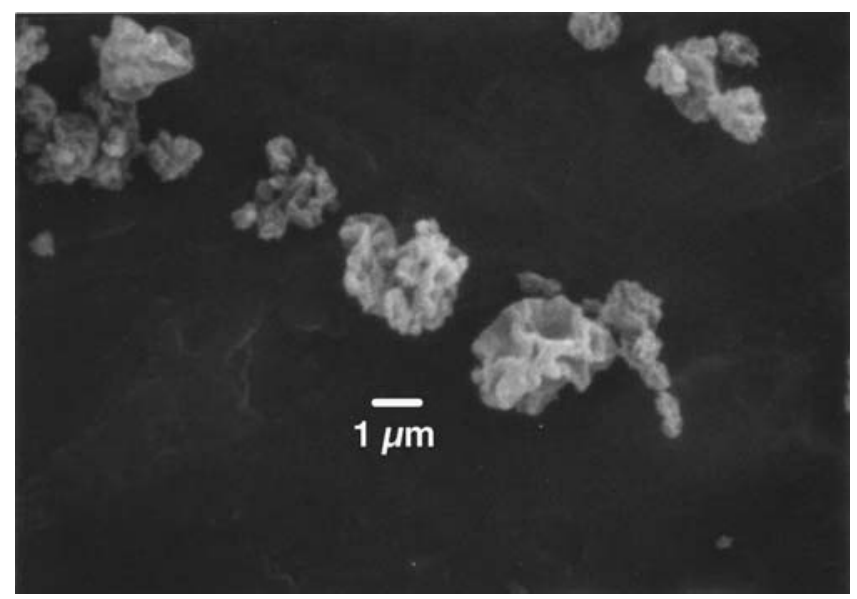

Fig. 10. SEM image of particles produced by CAN-BD from an aqueous solution containing $10 \mathrm{mg} / \mathrm{ml}$ trypsinogen (average aerodynamic diameter: $0.86 \mu \mathrm{m}, 95 \%<1.57 \mu \mathrm{m})$. 


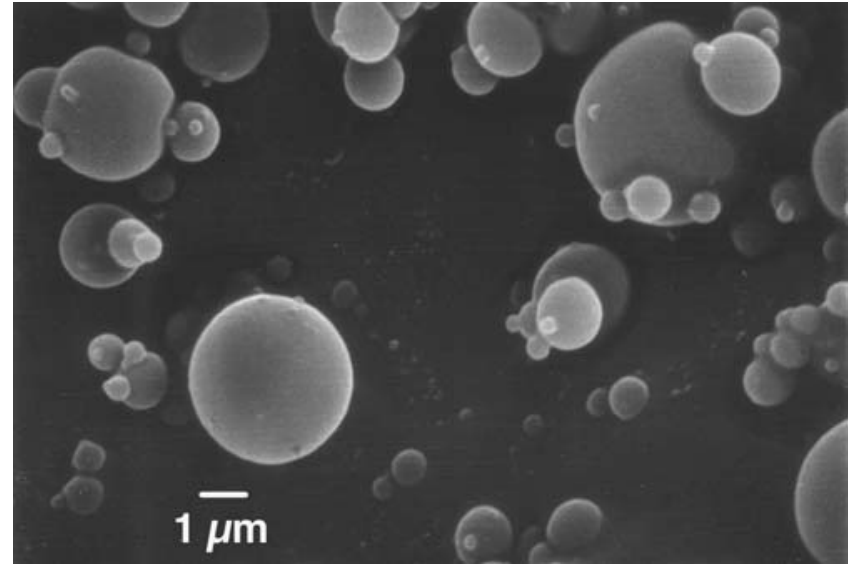

Fig. 11. SEM image of particles produced by CAN-BD from an aqueous solution containing $10 \%(w / w)$ trehalose (average aerodynamic diameter: $1.34 \mu \mathrm{m}, 95 \%<2.58 \mu \mathrm{m})$.

hollow spheres that collapsed. TEM visualization, an image of which is presented in Fig. 4, lends additional credence to the suggestion of hollow character by demonstrating that the particles are less dense in the centers, as seen by the lighter region in the center of particles.

While the goal of producing dry powders of anti-CD4 antibody by CAN-BD was primarily as an alternative to the traditional freeze-drying or spray-drying processes, the size distribution shown in Fig. 5 indicates that these powders are also suitable for delivery by inhalation. Average aerodynamic size of the particles was $1.4 \mu \mathrm{m}$ [squarely centered in the 1 to $3 \mu \mathrm{m}$ range recommended by Corkery (4)] with $95 \%$ of the particles less than $3.5 \mu \mathrm{m}$ in diameter. The distribution in Fig. 5 is representative of all the anti-CD4 antibody powders generated by CAN-BD. In addition, final moisture content of the powders as determined by Karl Fischer titration was 2\% or less, a value targeted as desirable for stability of dry formulations of proteins produced by freeze-drying (1).

A concern during the production of dry protein formulations by any process is that of protein aggregation. Figure 6 shows that the anti-CD4 antibody formulation was successfully processed by CAN-BD without the irreversible formation of any aggregates. The starting material and the

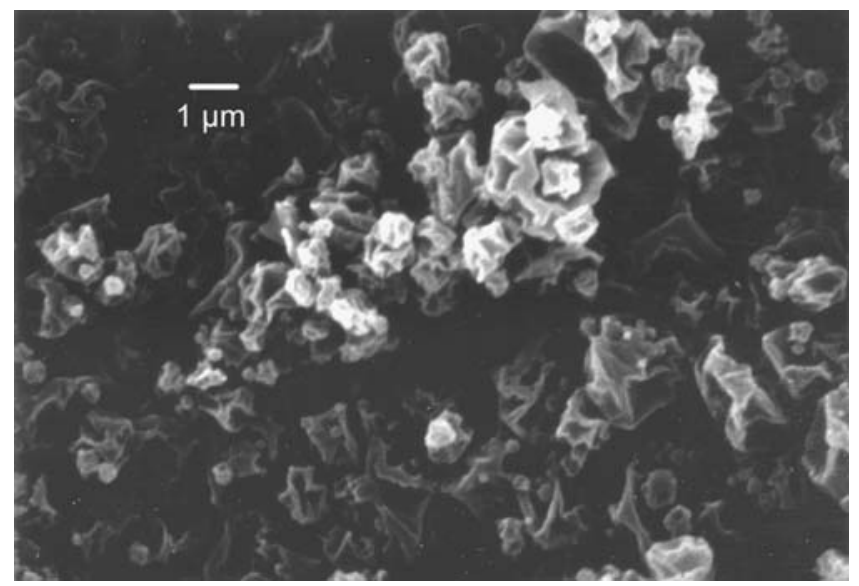

Fig. 12. SEM image of particles produced by CAN-BD from an aqueous solution containing $10 \mathrm{mg} / \mathrm{ml}$ trypsinogen and $4 \%(w / w)$ trehalose (average aerodynamic diameter: $1.02 \mu \mathrm{m}, 95 \%<2.06 \mu \mathrm{m}$ ).

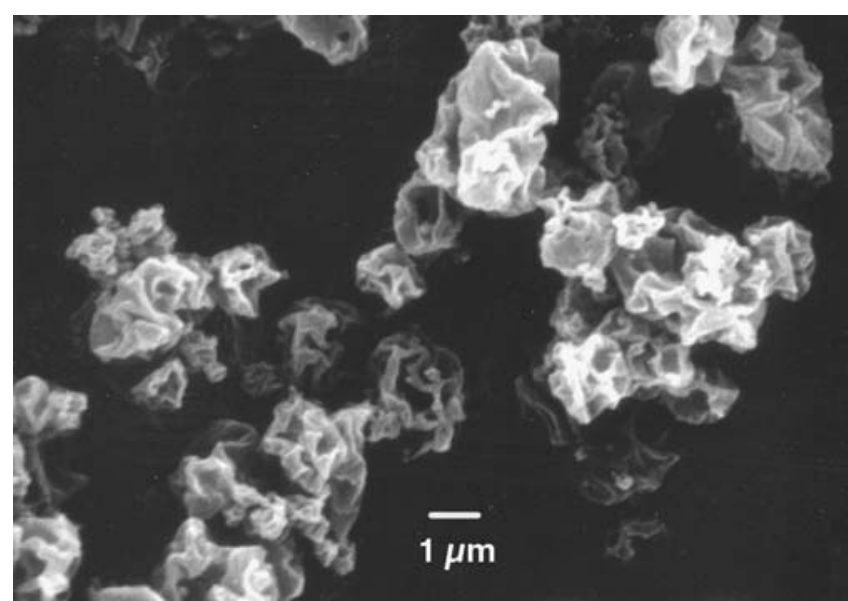

Fig. 13. SEM image of particles produced by CAN-BD from an aqueous solution containing $10 \mathrm{mg} / \mathrm{ml}$ trypsinogen and $1 \%(w / w)$ trehalose (average aerodynamic diameter: $0.90 \mu \mathrm{m}, 95 \%<1.56 \mu \mathrm{m}$ ).

rehydrated CAN-BD powder display essentially identical size-exclusion chromatography (SEC) profiles. Protein aggregation due to CAN-BD processing was also not observed by SEC for any of the other anti-CD4 antibody powders produced by CAN-BD (data not shown).

Preparation of stable and active anti-CD4 antibody powders by CAN-BD is demonstrated by the full retention of biological activity. Table IV shows that the ELISA antigen binding activity of the reconstituted CAN-BD processed antiCD4 antibody powder is statistically no different from that of the bulk starting solution. The data also demonstrate that in terms of binding activity retention, CAN-BD processing performs equally well as lyophilization. It should be noted that the binding assay was performed on CAN-BD particles rehydrated after 3 months of storage at room temperature, indicating that the CAN-BD anti-CD4 antibody powders are stable upon storage.

The reproducibility of generating anti-CD4 antibody powders by CAN-BD without significant structural perturbation is demonstrated by consistent and comparable secondary structure of the dried protein, not only for powders generated under very similar processing conditions, but also for powders

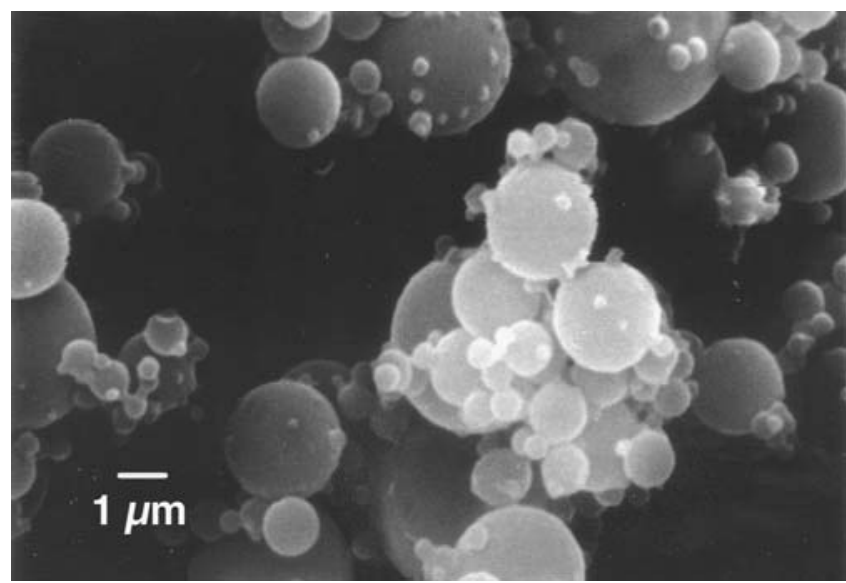

Fig. 14. SEM image of particles produced by CAN-BD from an aqueous solution containing $5 \%(\mathrm{w} / \mathrm{w})$ sucrose (average aerodynamic diameter: $1.45 \mu \mathrm{m}, 95 \%<2.92 \mu \mathrm{m})$. 


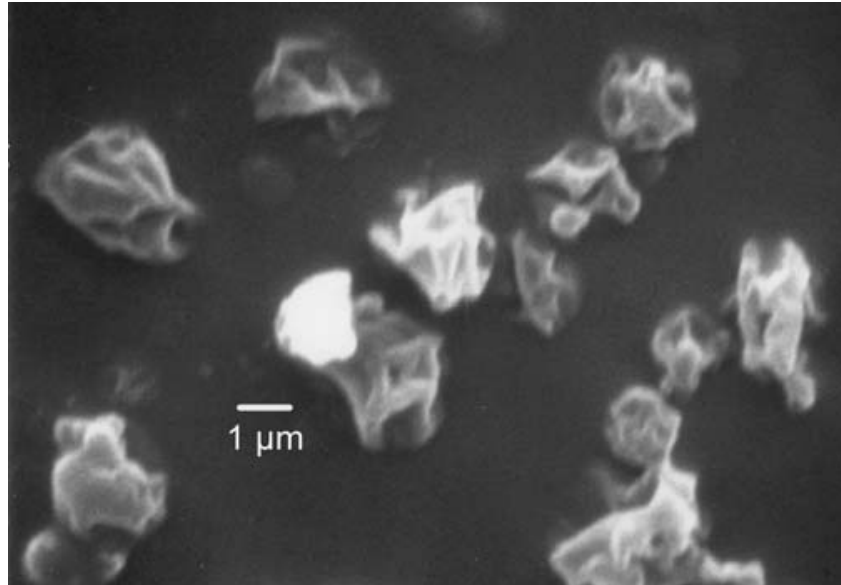

Fig. 15. SEM image of particles produced by CAN-BD from an aqueous solution containing $10 \mathrm{mg} / \mathrm{ml}$ trypsinogen and $4 \%(w / w)$ sucrose (average aerodynamic diameter: $1.06 \mu \mathrm{m}, 95 \%<1.93 \mu \mathrm{m}$ ).

produced by CAN-BD at different drying temperatures. Second-derivative IR spectra in the conformationally sensitive amide I region (Fig. 7) (119-121) demonstrate that the secondary structure for anti-CD4 antibody powder dried at $50^{\circ} \mathrm{C}$ is essentially identical (within experimental error) to that dried at about $30^{\circ} \mathrm{C}$. The spectra (not shown) for the other CAN-BD powders of anti-CD4 antibody also overlay within experimental error the spectra shown in Fig. 7. In addition, Fig. 7 shows that the secondary structure of antiCD4 antibody in the dry CAN-BD powders is substantially the same as that of native anti-CD4 antibody in aqueous solution prior to CAN-BD processing.

CAN-BD powder generation reproducibility is also demonstrated by the summary of particles sizes and residual moisture content presented in Table V. Mean aerodynamic diameters of the anti-CD4 antibody CAN-BD particle size distributions were typically $1.5 \mu \mathrm{m}$ with $95 \%$ of the particles almost invariably $\leq 5 \mu \mathrm{m}$. Equilibrium residual moisture content was in all cases $2 \%$ or less.

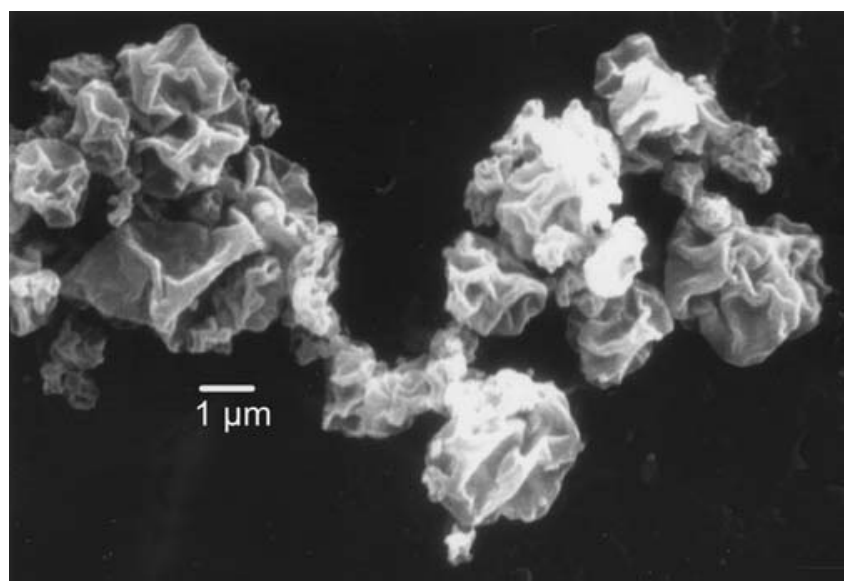

Fig. 16. SEM image of particles produced by CAN-BD from an aqueous solution containing $10 \mathrm{mg} / \mathrm{ml}$ trypsinogen and $1 \%(w / w)$ sucrose (average aerodynamic diameter: $0.87 \mu \mathrm{m}, 95 \%<1.56 \mu \mathrm{m}$ ).

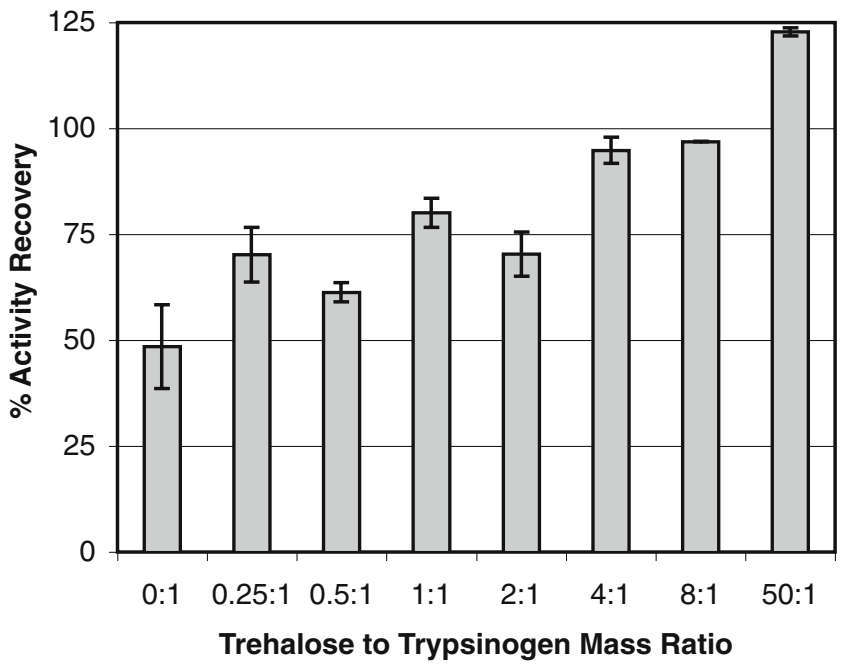

Fig. 17. Apparent activity recovery of trypsinogen stabilized with trehalose. The trypsinogen concentration in the original aqueous solution was in all cases $10 \mathrm{mg} / \mathrm{ml}$ except for the $50: 1$ ratio $(5 \mathrm{mg} / \mathrm{ml}$ trypsinogen). Enzymatic activity was determined using a previously established assay (123) with the appropriate modifications.

\section{$\alpha_{1}$-antitrypsin $(A A T)$}

We have successfully formed fine dry powders of the enzyme $\alpha_{1}$-antitrypsin (AAT) by CAN-BD. AAT (Cat. \# A6150) was purchased from Sigma-Aldrich Corp. (St. Louis, MO, USA) and used without further purification. Trehalose (Cat \# T-104-1) was purchased from Pfanstiehl Laboratories, Inc. (Waukegan, IL, USA). AAT solutions were prepared by dissolving a known mass of the solid, commercially lyophilized powder in the desired buffer solution.

Figure 8 is a representative SEM image of particles of AAT generated at $40^{\circ} \mathrm{C}$ drying temperature from an aqueous solution containing $2.8 \%(w / w)$ AAT and $4.6 \%(w / w)$ trehalose in $0.1 \mathrm{M}$ sodium phosphate, at $\mathrm{pH} 7.0$ with $0.1 \%$ $(w / w)$ Tween-20. The resulting dry powder consisted of particles with an average aerodynamic diameter of $2.2 \mu \mathrm{m}$, while $95 \%$ of the particles had a diameter of $<5.3 \mu \mathrm{m}$. Water content of the final dry powder was $1.8 \%$. AAT processed by CAN-BD into dry powder retained $98 \% \pm 2 \%$ of its original activity when reconstituted in water. Biological activity of AAT was determined using the elastase inhibitory activity assay described by Travis and Johnson (122).

Particles of AAT were also produced by CAN-BD at $50^{\circ} \mathrm{C}$ from an aqueous solution containing $4 \%(w / w)$ AAT and $4 \%$ $(w / w)$ trehalose in $0.1 \mathrm{M}$ sodium phosphate, $\mathrm{pH} 7.0$ with $0.01 \%$ $(w / w)$ Tween-20. The resulting dry powder displayed a qualitative morphology as observed by SEM (data not shown) that was very similar to that seen in Fig. 8 and consisted of particles with an average aerodynamic diameter of $1.9 \mu \mathrm{m}$ ( $95 \%$ of the particles had a diameter of $<5.4 \mu \mathrm{m}$ ). The water content of the final dry powder in this case was also determined to be $1.8 \%$. As before, AAT in the CAN-BD processed dry powder retained full activity, displaying 106\% $\pm 10 \%$ recovery of its original activity when reconstituted in water.

For both dry powder samples, the size-exclusion chromatography profiles of CAN-BD processed AAT were nearly identical to the AAT in the original unprocessed sample, 
indicating that CAN-BD processing caused no physical degradation or irreversible aggregation (data not shown).

\section{Trypsinogen}

The CAN-BD process was able to generate dry and stable particles of the model protein trypsinogen in the appropriate size range for pulmonary drug delivery. Trypsinogen (Cat \# LS003649) was obtained from the Worthington Biochemical Corporation (Lakewood, NJ, USA) and was used without further purification.

The stabilizing effect of two disaccharide sugars, sucrose and trehalose, on trypsinogen processed by CAN-BD was investigated. Sucrose (Cat \# S-124-1) and trehalose (Cat \# T104-1) were purchased from Pfanstiehl Laboratories. Each sugar was combined with the protein in varying ratios of sugar to protein. Protein concentration in the pre-CAN-BD solution was kept constant at $10 \mathrm{mg} / \mathrm{ml}$ in formulations in which the sugar concentrations varied from $0 \%, 0.25 \%, 0.5 \%$, $1 \%, 2 \%, 4 \%$, and $8 \%$ ( $w / w$; see Table VI). Another condition was also tested (protein concentrations and percentages of sugar refer to concentrations in the pre-CAN-BD solutions): $5 \mathrm{mg} / \mathrm{ml}$ trypsinogen with $25 \%$ sugar.

The average aerodynamic diameter of the particle was dependent on the concentration of total dissolved solids (TDS) in the initial aqueous solution. For concentrations ranging from $1 \%$ to $10 \%(w / w)$ TDS, the average aerodynamic diameters ranged from $0.8 \mu \mathrm{m}$ to $1.4 \mu \mathrm{m}$, respectively. From Table VI it can be seen that as the TDS increased in the aqueous solution, the corresponding average particle aerodynamic diameter in the dry powders (either with trehalose or sucrose as an excipient) also increased. This dependence of the particle size upon the initial solution concentration has also been reported elsewhere (110). An SEM image of the asreceived trypsinogen product is presented in Fig. 9 and shows it consists of very large flakes. Representative SEM images and particle size distributions of the CAN-BD processed trypsinogen formulations show the particles to be in the appropriate size range for the most effective pulmonary delivery (See Figs. 11, 12, 13, 14, 15 and 16 and Table VI). Fig. 10 shows an image of trypsinogen particles, generated from a $1 \%(w / w)$ aqueous solution. It shows that CAN-BD generated dimpled raisin-like particles with a mean aerodynamic diameter of $0.86 \mu \mathrm{m}$ and $95 \%$ of particles less than $1.57 \mu \mathrm{m}$. Fig. 11 shows an image of trehalose particles, without any protein, generated from a $10 \%(w / w)$ aqueous solution. It shows spherical particles with a mean aerodynamic diameter of $1.34 \mu \mathrm{m}$ and that $95 \%$ of the particles are less than $2.58 \mu \mathrm{m}$ in diameter. All trypsinogen-trehalose mixtures processed by CAN-BD showed increasingly dimpled or raisin-like particle morphology with increasing trypsinogen concentration. Upon inclusion of $20 \%$ or more trypsinogen (mass percent in the dried solid), the morphologies of the particles were all very similar, that is, raisin-like (see Figs. 12 and 13). Similar morphologies were observed for particles generated from trypsinogen formulations containing sucrose instead of trehalose. Figure 14 shows an image of sucrose particles that were synthesized as spheres. Similar to the formulations containing trehalose, Figs. 15 and 16 show that trypsinogen-sucrose particles have raisin-like morphologies upon inclusion of $20 \%$ or more trypsinogen (mass percent in the dried solid).
The presence of the excipients (i.e., sucrose or trehalose) preserves the activity of the enzyme through the micronization and drying of the CAN-BD process (Fig. 17 shows the results for trehalose; similar results were obtained for sucrose) (123). In the absence of a stabilizing sugar, the activity of the enzyme was only $48 \%$ of its original activity when redissolved in water after CAN-BD. Previous experiments have shown that most of the damage experienced by the protein occurs during the drying process, after the aerosol is generated (91). The addition of either sucrose or trehalose in fractions constituting $80 \%$ to $89 \%(w / w)$ of the TDS was able to improve the retained activity of the trypsinogen processed by CAN-BD to near $100 \%$. We have also measured the activity of the CAN-BD treated particles that have been stored in a vacuum chamber for 6 months over calcium sulfate desiccant. The activity of the particles remained virtually unchanged, indicating that the CAN-BD treated powders are stable for at least 6 months when kept dry at room temperature.

In formulations with very high sugar concentration ( $>95 \%$ of the TDS), we observed an apparent enzyme activity greater than $100 \%$ of the original. The trypsinogen was used in formulations as received, with no purification attempts prior to processing to remove any aggregated or denatured and inactive protein impurities. It is possible that some reversibly aggregated, denatured protein or improperly folded molecules were present in the as-received commercial product. During the $\mathrm{CO}_{2}$-pressurization-depressurization cycling in CAN-BD, such inactive trypsinogen molecules may have become renatured or refolded to an active conformation, thus explaining the apparent enhancement of the originally measured enzyme activity. Similar enhancements relative to original enzyme activity have been previously observed in CAN-BD studies with a different enzyme, lactate dehydrogenase $(11,117)$.

All trypsinogen-sugar formulations studied were analyzed by size exclusion chromatography (SEC) for the presence of soluble aggregates. No significant agglomeration of the protein after processing by CAN-BD was observed (data not shown)

To assist in the protection of the structural integrity of the protein in the dried state it is important to use excipients that will be in the amorphous rather than crystalline state (1). Both sucrose and trehalose are amorphous after processing by CAN-BD as confirmed by X-ray diffraction (data not shown).

\section{CONCLUSIONS}

After surveying the published literature, we conclude that SCF processes generally, and SCF anti-solvent processes particularly, have limited application to the preparation of powders and particles containing active proteins. This is due to the fact that all these SCF processes, excepting RESS, require the presence of organic solvents. One notable exception is the CAN-BD process, which can nebulize aqueous solutions without the use of an organic solvent, which almost invariably causes degradation of sensitive biomolecules and vaccines. CAN-BD (or supercritical-assisted atomization or effervescent atomization) uses a dense gas (near-critical or supercritical $\mathrm{CO}_{2}$ ), not as a solvent or anti-solvent, but as a tool to facilitate aerosolizing a solution of interest to form 
microdroplets and microbubbles, which rapidly dry to produce microparticles and nanoparticles. CAN-BD has been successfully applied to a wide range of substances (e.g., smallmolecule pharmaceuticals, protein therapeutics and various excipients) formulated as aqueous or organic (e.g., methanol, ethanol, acetone, etc.) solutions. The resulting powders routinely consist of particles with mean aerodynamic diameter between about 1 to $2 \mu \mathrm{m}$, with $95 \%$ of the particles usually less than 3 to $5 \mu \mathrm{m}$ in diameter, making such powders suitable for use in dry powder inhalers or in metered dose inhalers. In addition to these desirable particle size characteristics, appropriately formulated protein-containing particles can be readily produced by CAN-BD without process-induced physical degradation (e.g., protein aggregation) or unacceptable loss of biological activity. This has been repeatedly demonstrated, in previous publications (11,69-75,91,92,101, $105,116,117$ ) with various biologicals (such as the enzymes lysozyme and lactate dehydrogenase, human $\operatorname{IgG}$ antibody, aluminum hydroxide adjuvanted hepatitis B surface antigen, and attenuated live virus measles vaccine) and in this publication with two therapeutically interesting proteins (anti-CD4 antibody and AAT) and a model enzyme (trypsinogen). Fine dry powders of anti-CD4 antibody or AAT, produced by CAN-BD from buffered solutions containing sugars and surfactants as stabilizing excipients, retained full biological activity upon redissolution with water and no detectable process-induced aggregation was observed by size-exclusion chromatography. Enzymatic activity of trypsinogen was essentially fully retained when sucrose or trehalose was included at $80 \%$ or more of the dry powder mass. Apparent activities greater than $100 \%$ of the original asreceived enzyme were reproducibly achieved for trypsinogen formulations that contained very high sugar content (98-99\% of the dry powder mass). Presumably, these enhanced activities occur when previously inactive protein molecules are returned to a native conformation through some as yet unknown mechanism during the CAN-BD processing $\left(\mathrm{CO}_{2}\right.$ pressurization, depressurization, and aerosolization and drying) of trypsinogen in a favorable environment (i.e., high sugar concentrations). Similar activity enhancement results have been previously observed for another enzyme, lactate dehydrogenase $(11,117)$.

\section{ACKNOWLEDGMENTS}

The authors gratefully acknowledge the partial financial support of the Foundation for the National Institutes of Health through Grant 1077 of the Grand Challenges in Global Health Initiative, the NIH SBIR Program (Grant No. 1 R43 AI053906-01A1) and the Colorado Tobacco Research Program (Award No. 1R-031). For their help in collecting and analyzing IR data, we also thank Dr. Derrick Katayama, Dr. Sampathkumar Krishnan and Dr. Yongsung Kim, all formerly in Dr. John Carpenter's laboratory in the School of Pharmacy at the University of Colorado Health Sciences Center (Denver). The SEC and ELISA work provided by the Analytical Service at Biogen Idec Inc. (San Diego, CA) are highly appreciated. Finally, we also thank Dr. Brian Quinn, at Aktiv-Dry LLC, for enlightening discussions and help in editing this manuscript, Jessica Burger for help preparing the manuscript, and Dr. Chi-Dean Liang, Helena
Meresman, Christopher M. Werth, and Tom Walsh, who are past members of the University of Colorado research group, for their laboratory assistance and helpful discussions.

Open Access This article is distributed under the terms of the Creative Commons Attribution Noncommercial License which permits any noncommercial use, distribution, and reproduction in any medium, provided the original author(s) and source are credited.

\section{REFERENCES}

1. W. Wang. Lyophilization and development of solid protein pharmaceuticals. Int J Pharm. 203:1-60 (2000) doi:10.1016/ S0378-5173(00)00423-3.

2. G. Lee. Spray-drying of Proteins. In J. F. Carpenter, and M. C. Manning (eds.), Rational Design of Stable Protein Formulations: Theory and Practice, Pharmaceutical Biotechnology, Volume 13, Kluwer Academic/Plenum Publishers, New York, 2002, pp. 135158.

3. K. A. Johnson. Preparation of peptide and protein powders for inhalation. Adv Drug Delivery Rev. 26:3-15 (1997) doi:10.1016/ S0169-409X(97)00506-1.

4. K. Corkery. Inhalable drugs for systemic therapy. Respir Care. 45:831-835 (2000).

5. J. Jung, and M. Perrut. Particle design using supercritical fluids: Literature and patent survey. J Supercrit Fluids. 20:179-219 (2001) doi:10.1016/S0896-8446(01)00064-X.

6. N. Jovanovic, A. Bouchard, G. W. Hofland, G. J. Witkamp, D. J. A. Crommelin, and W. Jiskoot. Stabilization of proteins in dry powder formulations using supercritical fluid technology. Pharm Res. 21:1955-1969 (2004) doi:10.1023/B:PHAM.0000048185.09483.e7.

7. S. A. Shoyele, and S. Cawthorne. Particle engineering techniques for inhaled biopharmaceuticals. Adv Drug Delivery Rev. 58:1009-1029 (2006) doi:10.1016/j.addr.2006.07.010.

8. R. E. Sievers, and U. Karst. Methods for fine particle formation. US Pat. 5,639,441, June 17, 1997.

9. R. E. Sievers, and U. Karst. Methods and apparatus for fine particle formation. Eur. Pat. EP 0677332 B1, 27 February 2002.

10. R. E. Sievers, S. P. Sellers, and J. F. Carpenter. Supercritical fluid-assisted nebulization and bubble drying. Chinese Pat. CN1368875, September 11, 2002.

11. R. E. Sievers, S. P. Sellers, and J. F. Carpenter. Supercritical fluid-assisted nebulization and bubble drying. US Pat. 6,630,121 B1, October 7, 2003.

12. R. E. Sievers, S. P. Sellers, and J. F. Carpenter. Supercritical fluid-assisted nebulization and bubble drying. Australian Pat. AU782916, September 82005.

13. D. E. Yocum, A. M. Solinger, J. Tesser, O. Gluck, M. Cornett, F. O’Sullivan, K. Nordensson, B. Dallaire, C. D. Shen, and J. Lipani. Clinical and immunologic effects of a PRIMATIZED (R) anti-CD4 monoclonal antibody in active rheumatoid arthritis: Results of a phase I, single dose, dose escalating trial. J Rheumatol. 25:1257-1262 (1998).

14. R. W. Carrell, and D. A. Lomas. Alpha1-antitrypsin deficiency-a model for conformational diseases. N Engl J Med. 346:45-53 (2002) doi:10.1056/NEJMra010772.

15. A. Colman. Dolly, Polly and other 'ollys': likely impact of cloning technology on biomedical uses of livestock. Genet Anal-Biomol Eng. 15:167-173 (1999) doi:10.1016/S1050-3862(99)00022-4.

16. G. Doring. Serine proteinase inhibitor therapy in alpha(1)antitrypsin inhibitor deficiency and cystic fibrosis. Pediatr Pulmonol. 28:363-375 (1999) doi:10.1002/(SICI)1099-0496 (199911)28:5<363::AID-PPUL9>3.0.CO;2-\#.

17. J. B. Hannay, and J. Hogarth. On the solubility of solids in gases. Proc $R$ Soc London. 29:324 (1879) doi:10.1098/ rspl.1879.0054.

18. M. B. King, and T. R. Bott. Introduction. In M. B. King, and T. R. Bott (eds.), Extraction of Natural Products Using Near- 
Critical Solvents, Blackie Academic \& Professional, Glasgow, 1993, pp. 1-33.

19. S. J. Prestrelski, N. Tedeschi, T. Arakawa, and J. F. Carpenter. Dehydration-induced conformational transitions in proteins and their inhibition by stabilizers. Biophys $J$. 65: 661-671 (1993).

20. S. J. Prestrelski, T. Arakawa, and J. F. Carpenter. Structure of proteins in lyophilized formulations using fourier-transform infrared-spectroscopy. ACS Symp Ser. 567:148-169 (1994).

21. K. Griebenow, and A. M. Klibanov. Lyophilization-induced reversible changes in the secondary structure of proteins. Proc Natl Acad Sci USA. 92:10969-10976 (1995) doi:10.1073/ pnas.92.24.10969.

22. J. F. Carpenter, S. J. Prestrelski, and T. Arakawa. Separation of Freezing-induced and drying-induced denaturation of lyophilized proteins using stress-specific stabilization.1. Enzymeactivity and calorimetric studies. Arch Biochem Biophys. 303:456-464 (1993) doi:10.1006/abbi.1993.1309.

23. S. J. Prestrelski, T. Arakawa, and J. F. Carpenter. Separation of freezing-induced and drying-induced denaturation of lyophilized proteins using stress-specific stabilization.2. Structural studies using infrared-spectroscopy. Arch Biochem Biophys. 303:465-473 (1993) doi:10.1006/abbi.1993.1310.

24. L. Kreilgaard, S. Frokjaer, J. M. Flink, T. W. Randolph, and J. F. Carpenter. Effects of additives on the stability of recombinant human factor XIII during freeze-drying and storage in the dried solid. Arch Biochem Biophys. 360:121-134 (1998) doi:10.1006/abbi.1998.0948.

25. A. Engwicht, U. Girreser, and B. W. Muller. Critical properties of lactide-co-glycolide polymers for the use in microparticle preparation by the Aerosol Solvent Extraction System. Int $J$ Pharm. 185:61-72 (1999) doi:10.1016/S0378-5173(99)00127-1.

26. R. T. Bustami, H. K. Chan, F. Dehghani, and N. R. Foster Generation of protein micro-particles using high pressure modified carbon dioxide. Proceedings of the 5th International Symposium on Supercritical Fluids, 8-12 April, Atlanta, GA, USA (2000).

27. R. T. Bustami, H. K. Chan, F. Dehghani, and N. R. Foster. Generation of micro-particles of proteins for aerosol delivery using high pressure modified carbon dioxide. Pharm Res. 17:1360-1366 (2000) doi:10.1023/A:1007551006782.

28. R. Sloan, M. Tservistas, M. E. Hollowood, L. Sarup, G. O. Humphreys, P. York, W. Ashraf, and M. Hoare. Controlled particle formation of biological material using supercritical fluids. Proceedings of the 6th Meeting on Supercritical Fluids: Chemistry and Materials, M. Poliakoff, M.W. George, and S.M. Howdle (eds.), 10-13 April, Nottingham (UK), pp. 169-174 (1999).

29. L. Sarup, M. T. Servistas, R. Sloan, M. Hoare, and G. O. Humphreys. Investigation of supercritical fluid technology to produce dry particulate formulations of antibody fragments. Trans Inst Chem Eng, C. 78:101-104 (2000) doi:10.1205/096030800532815.

30. M. Hanna, and P. York. Method and apparatus for the formation of particles. US Pat. 5,851,453, December 22, 1998.

31. M. Hanna, and P. York. Method and apparatus for the formation of particles. US Pat. US 6,063,138, May 16, 2000.

32. P. Pallado, L. Benedetti, and L. Callegaro. Nanospheres comprising a biocompatible polysaccharide. US Pat. US 6,214,384 B1, April 10, 2001.

33. J. W. Tom, G. B. Lim, P. G. Debenedetti, and R. K. Prudhomme. Applications of supercritical fluids in the controlled release of drugs. ACS Symp Ser. 514:238-257 (1993).

34. P. G. Debenedetti, J. W. Tom, S. D. Yeo, and G. B. Lim. Application of supercritical fluids for the production of sustained delivery devices. J Controlled Release. 24:27-44 (1993) doi:10.1016/0168-3659(93)90166-3.

35. M. Sarkari, I. Darrat, and B. L. Knutson. CO2 and fluorinated solvent-based technologies for protein microparticle precipitation from aqueous solutions. Biotechnol Progr. 19:448-454 (2003) doi:10.1021/bp0255513.

36. N. Elvassore, A. Bertucco, and P. Caliceti. Production of proteinpolymer micro-capsules by supercritical anti-solvent techniques. Proceedings of the 5th International Symposium on Supercritical Fluids, 8-12 April, Atlanta, GA, USA (2000).

37. M. C. Manning, T. W. Randolph, E. Shefter, and R. F. Falk. Solubilization of pharmaceutical substances in an organic solvent and preparation of pharmaceutical powders using the same. US Pat. US 5,770,559, June 23, 1998.

38. M. C. Manning, T. W. Randolph, E. Shefter, and R. F. Falk. Solubilization of pharmaceutical substances in an organic solvent and preparation of pharmaceutical powders using the same. US Pat. US 5,981,474, November 9, 1999.

39. P. Pallado, L. Benedetti, and L. Callegaro. Nanospheres comprising a biocompatible polysaccharide. Eur. Pat. EP 0817 620 B1, 30 January 2002.

40. D. P. Nesta, J. S. Elliott, and J. P. Warr. Supercritical fluid precipitation of recombinant human immunoglobulin from aqueous solutions. Biotechnol Bioeng. 67:457-464 (2000) doi:10.1002/ (SICI)1097-0290(20000220)67:4<457::AID-BIT9>3.0.CO;2-K.

41. S. D. Yeo, G. B. Lim, P. G. Debenedetti, and H. Bernstein. Formation of microparticulate protein powders using a supercritical fluid antisolvent. Biotechnol Bioeng. 41:341-346 (1993) doi:10.1002/bit.260410308.

42. R. Thiering, F. Dehghani, and N. R. Foster. Micronization of model proteins using compressed carbon dioxide. Proceedings of the 5th International Symposium on Supercritical Fluids, 812 April, Atlanta, GA, USA (2000).

43. R. Thiering, F. Dehghani, A. Dillow, and N. R. Foster. The influence of operating conditions on the dense gas precipitation of model proteins. J Chem Technol Biotechnol. 75:29-41 (2000) doi:10.1002/(SICI)1097-4660(200001)75:1<29::AIDJCTB172>3.0.CO;2-E.

44. R. Thiering, F. Dehghani, A. Dillow, and N. R. Foster. Solvent effects on the controlled dense gas precipitation of model proteins. J Chem Technol Biotechnol. 75:42-53 (2000) doi:10.1002/(SICI)1097-4660(200001)75:1<42::AIDJCTB173>3.0.CO;2-C.

45. M. A. Winters, B. L. Knutson, P. G. Debenedetti, H. G. Sparks, T. M. Przybycien, C. L. Stevenson, and S. J. Prestrelski. Precipitation of proteins in supercritical carbon dioxide. $J$ Pharm Sci. 85:586-594 (1996) doi:10.1021/js950482q.

46. M. A. Winters, P. G. Debenedetti, J. Carey, H. G. Sparks, S. U. Sane, and T. M. Przybycien. Long-term and high-temperature storage of supercritically-processed microparticulate protein powders. Pharm Res. 14:1370-1378 (1997) doi:10.1023/ A:1012112503590.

47. N. Elvassore, A. Bertucco, and P. Caliceti. Production of insulin-loaded poly(ethylene glycol)/poly(l-lactide) (PEG/ PLA) nanoparticles by gas antisolvent techniques. $J$ Pharm Sci. 90:1628-1636 (2001) doi:10.1002/jps.1113.

48. N. Elvassore, A. Bertucco, and P. Caliceti. Production of protein-loaded polymeric microcapsules by compressed $\mathrm{CO} 2$ in a mixed solvent. Ind Eng Chem Res. 40:795-800 (2001) doi:10.1021/ie0004904.

49. W. K. Snavely, B. Subramaniam, R. A. Rajewski, and M. R. Defelippis. Micronization of insulin from halogenated alcohol solution using supercritical carbon dioxide as an antisolvent. $J$ Pharm Sci. 91:2026-2039 (2002) doi:10.1002/jps.10193.

50. G. Muhrer, and M. Mazzotti. Precipitation of lysozyme nanoparticles from dimethyl sulfoxide using carbon dioxide as antisolvent. Biotechnol Progr. 19:549-556 (2003) doi:10.1021/ bp0256317.

51. P. Chattopadhyay, and R. B. Gupta. Protein nanoparticles formation by supercritical antisolvent with enhanced mass transfer. AlChE J. 48:235-244 (2002) doi:10.1002/aic.690480207.

52. S. Moshashaee, M. Bisrat, R. T. Forbes, H. Nyqvist, and P. York. Supercritical fluid processing of proteins I: Lysozyme precipitation from organic solution. Eur J Pharm Sci. 11:239245 (2000) doi:10.1016/S0928-0987(00)00108-1.

53. L. S. Tu, F. Dehghani, and N. R. Foster. Micronisation and micro encapsulation of pharmaceuticals using a carbon dioxide antisolvent. Powder Technol. 126:134-149 (2002) doi:10.1016/ S0032-5910(02)00045-1.

54. N. Jovanovic, A. Bouchard, G. W. Hofland, G. J. Witkamp, D. J. A. Crommelin, and W. Jiskott. Distinct effects of sucrose and trehalose on protein stability during supercritical fluid drying and freeze-drying. Eur J Pharm Sci. 27:336-345 (2006) doi:10.1016/j.ejps.2005.11.003.

55. N. R. Foster, H. K. Chan, R. T. Bustami, and F. Dehghani. Effect of Nozzle Design on Protein Microparticles in the ASES Process. Proceedings of the Sixth Conference on Supercritical 
Fluids and Their Applications, E. Reverchon (ed.), Maiori, Italy, pp. 359-364 (2001).

56. R. T. Forbes, R. Sloan, I. Kibria, M. E. Hollowood, G. O. Humphreys, and P. York. Production of Stable Protein Particles: A Comparison of Freeze, Spray and Supercritical Drying. Proceedings of the World Congress on Particle Technology 3, 7-9 July, Brighton, UK (1998).

57. R. Sloan, M. E. Hollowood, G. O. Humphreys, W. Ashraf, and P. York. Supercritical fluid processing: preparation of stable protein particles. Proceedings of the 5th Meeting on Supercritical Fluids, M. Perrut and P. Subra (eds.), 23-25 March, Nice, France, pp. 301-306 (1998).

58. D. J. Gilbert, S. Palakodaty, R. Sloan, and P. York. Particle Engineering for Pharmaceutical Applications - A Process Scale Up. Proceedings of the 5th International Symposium on Supercritical Fluids, 8-12 April, Atlanta, GA, USA (2000).

59. S. Moshashaee, M. Bisrat, R. T. Forbes, E. A. Quinn, H. Nyqvist, and P. York. Supercritical fluid processing of proteins: lysozyme precipitation from aqueous solution. J Pharm Pharmacol. 55:185-192 (2003) doi:10.1211/002235702504.

60. J. F. Carpenter, S. J. Prestrelski, and A. Dong. Application of infrared spectroscopy to development of stable lyophilized protein formulations. Eur J Pharm Biopharm. 45:231-238 (1998) doi:10.1016/S0939-6411(98)00005-8.

61. H. Ogino, and H. Ishikawa. Enzymes which are stable in the presence of organic solvents. J Biosci Bioeng. 91:109-116 (2001) doi:10.1263/jbb.91.109.

62. T. P. Castor, and G. T. Hong. Method for size reduction of proteins. US Pat. 6,051,694, April 18, 2000.

63. T. J. Young, K. P. Johnston, K. Mishima, and H. Tanaka. Encapsulation of lysozyme in a biodegradable polymer by precipitation with a vapor-over-liquid antisolvent. J Pharm Sci. 88:640-650 (1999) doi:10.1021/js980237h.

64. K. Mishima, K. Matsuyama, D. Tanabe, S. Yamauchi, T. J. Young, and K. P. Johnston. Microencapsulation of proteins by rapid expansion of supercritical solution with a nonsolvent. AlChE J. 46:857-865 (2000) doi:10.1002/aic.690460418.

65. I. R. Dos Santos, J. Richard, B. Pech, C. Thies, and J. P. Benoit. Microencapsulation of protein particles within lipids using a novel supercritical fluid process. Int J Pharm. 242:69-78 (2002) doi:10.1016/S0378-5173(02)00149-7.

66. I. R. Dos Santos, J. Richard, C. Thies, B. Pech, and J. P. Benoit. A supercritical fluid-based coating technology. 3: Preparation and characterization of bovine serum albumin particles coated with lipids. J Microencapsulation. 20:110-128 (2003) doi: 10.1080/02652040210162630.

67. J. Richard, F. Deschamps, A. M. De Conti, and O. Thomas. Using a supercritical fluid-based process: Application to injectable sustained-release formulations of biomolecules. ACS Symp Ser. 924:250-261 (2006).

68. M. J. Whitaker, J. Y. Hao, O. R. Davies, G. Serhatkulu, S. Stolnik-Trenkic, S. M. Howdle, and K. M. Shakesheff. The production of protein-loaded microparticles by supercritical fluid enhanced mixing and spraying. $J$ Controlled Release. 101:85-92 (2005) doi:10.1016/j.jconrel.2004.07.017.

69. R. E. Sievers, B. P. Quinn, S. P. Cape, J. A. Searles, C. S. Braun, P. A. Bhagwat, L. G. Rebits, D. H. McAdams, J.L. Burger, J.A. Best, L. Lindsay, M.T. Hernandez, T. Iacovangelo, D. Kristensen, and D. Chen. Near-critical Fluid Micronization of Stabilized Vaccines, Antibiotics, and Anti-virals. Proceedings of the 8th Conference on Supercritical Fluids and Their Applications: Chemical Reactivity and Material Processing in Supercritical Fluids, 28-31 May, Ischia, Italy, pp. 407-412 (2006).

70. R. E. Sievers, B. P. Quinn, S. P. Cape, J. A. Searles, C. S. Braun, P. Bhagwat, L. G. Rebits, D. H. McAdams, J. L. Burger, J. A. Best, L. Lindsay, M. T. Hernandez, K. O. Kisich, T. Iacovangelo, D. Kristensen, and D. Chen. Near-critical fluid micronization of stabilized vaccines, antibiotics and anti-virals. J Supercrit Fluids. 42:385-391 (2007) doi:10.1016/j.supflu.2007.03.001.

71. R. E. Sievers, D. J. Bennett, S. P. Cape, C. S. Braun, J. A. Best, A. L. Morin, C. A. Pelzmann, B. P. Quinn, P. Pathak, J. A. Searles, P. A. Bhagwat, L. G. Rebits, J. L. Burger, and D. H. McAdams. Micronization of measles vaccine and siRNA by CAN-BD for aerosol delivery by air expansion of powders with a PuffHalerTM. Proceedings of the RDD Europe 2007, R.N.
Dalby, P.R. Byron, J. Peart, and J.D. Suman (eds.), April 17-20, Paris, France, pp. 231-234 (2007).

72. S. P. Cape, C. S. Braun, J. A. Best, J. L. Burger, D. H. McAdams, P. A. Bhagwat, L. G. Rebits, P. Pathak, D. J. Bennett, and R. E. Sievers. Formulation and inhalable powder preparation of live virus measles vaccine by CAN-BD. $J$ Aerosol Med. 20:198-199 (2007).

73. R. E. Sievers. Stabilization, micronization, and rapid gentle drying by CAN-BD of fine particle aerosols for respiratory delivery of vaccines, antibiotics and anti-virals. J Aerosol Med. 20:217 (2007).

74. J. L. Burger, S. P. Cape, C. S. Braun, D. H. McAdams, J. A. Best, P. A. Bhagwat, P. Pathak, L. G. Rebits, and R. E. Sievers. Stabilizing formulations for inhalable powders of live attenuated measles virus vaccine. J Aerosol Med. 21:25-34 (2008) doi: 10.1089/jamp.2007.0658.

75. R. E. Sievers, S. P. Cape, K. O. Kisich, D. J. Bennett, C. S. Braun, J. L. Burger, J. A. Best, D. H. McAdams, N. A. Wolters, B. P. Quinn, J. A. Searles, D. M. Krank, P. Pathak, P. A. Bhagwat, and L. G. Rebits. Challenges of Developing a Stable Dry Powder Live Viral Vaccine. Proceedings of the Respiratory Drug Delivery 2008, R.N. Dalby, P.R. Byron, J. Peart, and J.D. Suman (eds.), May 11-15, Scottsdale, AZ (USA), pp. 281-290 (2008).

76. A. M. Abdul-Fattah, V. Truong-Le, L. Yee, L. Nguyen, D. S. Kalonia, M. T. Cicerone, and M. J. Pikal. Drying-induced variations in physico-chemical properties of amorphous pharmaceuticals and their impact on stability (I): Stability of a monoclonal antibody. J Pharm Sci. 96:1983-2008 (2007) doi: 10.1002/jps.20859.

77. A. M. Abdul-Fattah, V. Truong-Le, L. Yee, E. Pan, Y. Ao, D. S. Kalonia, and M. J. Pikal. Drying-induced variations in physicochemical properties of amorphous pharmaceuticals and their impact on stability II: Stability of a vaccine. Pharm Res. 24:715727 (2007) doi:10.1007/s11095-006-9191-2.

78. V. Truong-Le, and B. Pham. Preservation of bioactive materials by spray drying. US Pat. App. US 2003/0215515 A1, Nov. 20 2003.

79. V. Truong-Le, and T. Scherer. High pressure spray-dry of bioactive materials. US Pat. App. US 2004/185091 A1, Sep. 23, 2004.

80. V. Truong-Le, and T. Scherer. High pressure spray-dry of bioactive materials. US Pat. App. US 2006/002862 A1, Jan. 5, 2006.

81. V. Truong-Le, and B. Pham. Preservation of bioactive materials by spray drying. US Pat. US 7,258,873, Nov. 202007.

82. B. Y. Shekunov, P. Chattopadhyay, and J. S. Seitzinger. Lyophilization method and apparatus for producing particles. US Pat. 6,931,888, August 23, 2005.

83. V. Truong-Le, B. V. Pham, J. F. Carpenter, R. Seid, and T. W. Randolph. Spray Freeze Dry of Compositions for Pulmonary Administration. US Pat. App. US 2004/0042971 A1, Mar. 4 2004.

84. V. Truong-Le, B. V. Pham, J. F. Carpenter, R. Seid, and T. W. Randolph. Spray Freeze Dry of Compositions for Intranasal Administration. US Pat. App. US 2004/0042972 A1, Mar. 4 2004.

85. B. Y. Shekunov, P. Chattopadhyay, and J. Seitzinger. Production of respirable particles using spray-freeze-drying with compressed $\mathrm{CO}_{2}$. Proceedings of the Respiratory Drug Delivery IX, R.N. Dalby, P.R. Byron, J. Peart, J.D. Suman, and S.J. Farr (eds.), April 25-29, Palm Desert, CA (USA), pp. 489-491 (2004).

86. E. Reverchon. Supercritical-assisted atomization to produce micro- and/or nanoparticles of controlled size and distribution. Ind Eng Chem Res. 41:2405-2411 (2002) doi:10.1021/ ie $010943 \mathrm{k}$.

87. E. Reverchon. Process for the production of micro and/or nano particles. Intl. Pat. App. WO 03/004142 A1, 16 January 2003.

88. E. Reverchon. Process for the production of micro and/or nano particles. US Pat. App. US 2004/0178529 A1, September 16, 2004.

89. R. E. Sievers, U. Karst, P. D. Milewski, S. P. Sellers, B. A. Miles, J. D. Schaefer, C. R. Stoldt, and C. Y. Xu. Formation of aqueous small droplet aerosols assisted by supercritical carbon dioxide. Aerosol Sci Technol. 30:3-15 (1999) doi:10.1080/ 027868299304840

90. R. E. Sievers, P. D. Milewski, S. P. Sellers, B. A. Miles, B. J. Korte, K. D. Kusek, G. S. Clark, B. Mioskowski, and J. A. Villa. 
Supercritical and near-critical carbon dioxide assisted lowtemperature bubble drying. Ind Eng Chem Res. 39:4831-4836 (2000) doi:10.1021/ie000190m.

91. S. P. Sellers, G. S. Clark, R. E. Sievers, and J. F. Carpenter. Dry powders of stable protein formulations from aqueous solutions prepared using supercritical $\mathrm{CO}_{2}$-assisted aerosolization. $J$ Pharm Sci. 90:785-797 (2001) doi:10.1002/jps.1032.

92. R. E. Sievers, E. T. S. Huang, J. A. Villa, J. K. Kawamoto, M. M. Evans, and P. R. Brauer. Low-temperature manufacturing of fine pharmaceutical powders with supercritical fluid aerosolization in a Bubble Dryer (R). Pure Appl Chem. 73:1299-1303 (2001) doi:10.1351/pac200173081299.

93. E. T. S. Huang, H. Y. Chang, S. P. Cape, L. Rinner, B. P. Quinn, and R. E. Sievers. Nanoparticle and microparticle generation with super- or near-critical carbon dioxide. Proceedings of the 6th International Symposium on Supercritical Fluids, 28-30 April, Versailles, France, pp. 1695-1700 (2003).

94. R. E. Sievers, E. T. S. Huang, J. A. Villa, G. Engling, and P. R. Brauer. Micronization of water-soluble or alcohol-soluble pharmaceuticals and model compounds with a low-temperature Bubble Dryer ${ }^{\circledR}$. J Supercrit Fluids. 26:9-16 (2003) doi:10.1016/ S0896-8446(02)00188-2.

95. J. A. Villa, E. T. S. Huang, S. P. Cape, and R. E. Sievers. Synthesis of composite microparticles with a mixing cross. Aerosol Sci Technol. 39:473-484 (2005).

96. M. Adler, and G. Lee. Stability and surface activity of lactate dehydrogenase in spray-dried trehalose. J Pharm Sci. 88:199208 (1999) doi:10.1021/js980321x.

97. R. E. Sievers, E. T. S. Huang, J. A. Villa, and T. R. Walsh. CAN-BD Process for Rapidly Forming and Drying Fine Particles. Proceedings of the 8th Meeting on Supercritical Fluids: Chemical Reactivity and Material Processing in Supercritical Fluids, M. Besnard and F. Cansell (eds.), 14-17 April, Bordeaux (France), pp. 73-78 (2002).

98. R. Thiering, F. Dehghani, and N.R. Foster. Current issues relating to anti-solvent micronisation techniques and their extension to industrial scales. J Supercrit Fluids. 21:159-177 (2001) doi:10.1016/S0896-8446(01)00090-0.

99. R. E. Sievers, P. D. Milewski, C. Y. Xu, U. Karst, J. RusicPavletic, K. D. Kusek, T. Mandal, W. C. Andersen, C. R. Stoldt, J. D. Schaefer, and B. A. Miles. Supercritical Fluid Emulsions with Aqueous Solutions for Forming Fine Particles of Pharmaceuticals and Metal Oxides. Proceedings of the 5th Meeting on Supercritical Fluids, M. Perrut and P. Subra (eds.), 23-25 March, Nice, France, pp. 273-274 (1998).

100. R. E. Sievers, P. D. Milewski, S. P. Sellers, K. D. Kusek, P. G. Kleutz, and B. A. Miles. Supercritical $\mathrm{CO}_{2}$-Assisted Methods for the Production and Pulmonary Administration of Pharmaceutical Aerosols. J Aerosol Sci. 29:S1271-S1272 (1998) doi: 10.1016/S0021-8502(98)90818-7.

101. R. E. Sievers, S. P. Cape, B. P. Quinn, J. A. Searles, J. A. Best, J. L. Burger, D. H. McAdams, and L. G. Rebits. Stabilization, Nebulization, and Near-ambient Temperature Drying of Measles Vaccine, IgG Antibody, TB Antibiotics, and Zanamivir. Proceedings of the Respiratory Drug Delivery X, R.N. Dalby, P.R. Byron, J. Peart, J.D. Suman, and S.J. Farr (eds.), April 2327, Boca Raton, FL (USA), pp. 401-404 (2006).

102. E. Reverchon, and A. Spada. Crystalline microparticles of controlled size produced by supercritical-assisted atomizatione. Ind Eng Chem Res. 43:1460-1465 (2004) doi:10.1021/ ie034111t.

103. E. Reverchon, and G. Della Porta. Particle design using supercritical fluids. Chem Eng Technol. 26:840-845 (2003) doi:10.1002/ceat.200300005.

104. E. Reverchon, G. Della Porta, and A. Spada. Ampicillin micronization by supercritical assisted atomization. $J$ Pharm Pharmacol. 55:1465-1471 (2003) doi:10.1211/0022357022043.

105. S. P. Cape, J. A. Villa, E. T. S. Huang, L. V. Rinner, S. M. Hibbard, J. A. Madsen, T. L. Piester, D. K. Alargov, B. P. Quinn, and R. E. Sievers. Manufacturing and coating nanoparticles and microparticles with dense carbon dioxide nebulization in mixing tees and crosses in a Bubble Dryer ${ }^{\circledR}$. Proceedings of the International Congress for Particle Technology, PARTEC 2004, March 16-18, Nuremberg, Germany (2004).
106. R. E. Sievers, G. Clark, J. A. Villa, D. Alargov, L. Rinner, S. P. Cape, and E. T. S. Huang. Micronization of inhalable drugs with liquid carbon dioxide at near ambient conditions. J Aerosol Med. 16:213 (2003).

107. E. Reverchon, and A. Spada. Erythromycin micro-particles produced by supercritical fluid atomization. Powder Technol. 141:100-108 (2004) doi:10.1016/j.powtec.2004.02.017.

108. E. Reverchon, G. Della Porta, A. Spada, and A. Antonacci. Griseofulvin micronization and dissolution rate improvement by supercritical assisted atomization. J Pharm Pharmacol. 56:1379-1387 (2004) doi:10.1211/0022357044751.

109. G. Della Porta, C. De Vittori, and E. Reverchon. Supercritical assisted atomization: A novel technology for microparticles preparation of an asthma-controlling drug. AAPS PharmSciTech. 6:E421-E428 (2005) doi:10.1208/pt060352.

110. E. T. S. Huang, H. Y. Chang, C. D. Liang, and R. E. Sievers. Fine particle pharmaceutical manufacturing using dense carbon dioxide mixed with aqueous or alcoholic solutions. ACS Symp Ser. 860:324-338 (2003).

111. C. Y. Xu, R. E. Sievers, U. Karst, B. A. Watkins, C. M. Karbiwnyk, W. C. Andersen, J. D. Schaefer, and C. R. Stoldt. Supercritical carbon dioxide assisted aerosolization for thin film deposition, fine powder generation, and drug delivery. In P.T. Anastas, and T.C. Williamson (eds.), Green Chemistry: Frontiers in Benign Chemical Synthesis and Processes, Oxford University Press, Oxford, 1998, pp. 312-335.

112. R. E. Sievers, J. A. Villa, S. P. Cape, D. K. Alargov, L. Rinner, E. T. S. Huang, and B. P. Quinn. Synthesis and coating respirable particles with a low volume mixing cross or tee. Proceedings of the Respiratory Drug Delivery IX, R.N. Dalby, P.R. Byron, J. Peart, J.D. Suman, and S.J. Farr (eds.), April 2529, Palm Desert, CA (USA), pp. 765-767 (2004).

113. E. Reverchon, R. Adami, I. De Marco, C. G. Laudani, and A. Spada. Pigment Red 60 micronization using supercritical fluids based techniques. J Supercrit Fluids. 35:76-82 (2005) doi: 10.1016/j.supflu.2004.10.010.

114. E. Reverchon, and G. Della Porta. Micronization of antibiotics by supercritical assisted atomization. J Supercrit Fluids. 26:243252 (2003) doi:10.1016/S0896-8446(02)00162-6.

115. E. Reverchon, and G. Della Porta. Terbutaline microparticles suitable for aerosol delivery produced by supercritical assisted atomization. Int J Pharm. 258:1-9 (2003) doi:10.1016/S03785173(03)00024-3.

116. R. E. Sievers, E. T. S. Huang, J. A. Villa, T. R. Walsh, H. V. Meresman, C. D. Liang, and S. P. Cape. Rapid Gentle Drying using Dense Carbon Dioxide to Form Fine Dry Powders. Proceedings of the Respiratory Drug Delivery VIII, R.N. Dalby, P.R. Byron, J. Peart, and S.J. Farr (eds.), May 12-16, Tucson, AZ (USA), pp. 675-677 (2002).

117. J. A. Villa, R. E. Sievers, and E. T. S. Huang. Bubble Drying To Form Fine Particles From Solutes In Aqueous Solutions. Proceedings of the 7th Meeting on Supercritical Fluids: Particle Design-Materials and Natural Products Processing, M. Perrut and E. Reverchon (eds.), 6-8 December, Antibes/Juan-Les-Pins (France), pp. 83-88 (2000).

118. A. Giessauf, and T. Gamse. A simple process for increasing the specific activity of porcine pancreatic lipase by supercritical carbon dioxide treatment. J Mol Catal B: Enzym. 9:57-64 (2000) doi:10.1016/S1381-1177(99)00084-3.

119. A. Dong, and W.S. Caughey. Infrared methods for study of hemoglobin reactions and structures. Methods Enzymol. 232:139-175 (1994) doi:10.1016/0076-6879(94)32047-0.

120. A. Dong, P. Huang, and W. S. Caughey. Protein secondary structures in water from second-derivative amide I infrared spectra. Biochemistry. 29:3303-3308 (1990) doi:10.1021/bi00465a022.

121. A. Dong, S. J. Prestrelski, S. D. Allison, and J. F. Carpenter. Infrared spectroscopic studies of lyophilization- and temperature-induced protein aggregation. J Pharm Sci. 84:415-424 (1995) doi:10.1002/jps.2600840407.

122. J. Travis, and D. Johnson. Human alpha-1-proteinase inhibitor. Methods Enzymol. 80:754-765 (1981) doi:10.1016/S0076-6879 (81)80057-2.

123. S. T. Tzannis, and S. J. Prestrelski. Activity-stability considerations of trypsinogen during spray drying: Effects of sucrose. $J$ Pharm Sci. 88:351-359 (1999) doi:10.1021/js980011e. 